\title{
Relative contributions of crust and mantle to the origin of the Bijli Rhyolite in a palaeoproterozoic bimodal volcanic sequence (Dongargarh Group), central India
}

\author{
S SEnsarma ${ }^{1, *}$, S HoERnes $^{2}$ and D MukhopadhyA ${ }^{3}$ \\ ${ }^{1}$ Department of Geology, St. Anthony's College, Shillong 793 001, India. \\ ${ }^{2}$ Mineralalogisch-Petrologisches Institut, der Universität Bonn, D- 53115 Bonn, Germany. \\ ${ }^{3}$ Department of Geology, University of Calcutta, Calcutta 700 019, India. \\ *e-mail: sensarma2002@yahoo.co.in
}

New mineralogical, bulk chemical and oxygen isotope data on the Palaeoproterozoic Bijli Rhyolite, the basal unit of a bimodal volcanic sequence (Dongargarh Group) in central India, and one of the most voluminous silicic volcanic expressions in the Indian Shield, are presented. The Bijli Rhyolite can be recognized as a poorly sorted pyroclastic deposit, and comprises of phenocrystic $\mathrm{K}$-feldspar + albite \pm anorthoclase set in fine-grained micro-fragmental matrix of quartz-feldsparsericite-chlorite-iron-oxide \pm calcite. The rocks are largely metaluminous with high $\mathrm{SiO}_{2}, \mathrm{Na}_{2} \mathrm{O}+$ $\mathrm{K}_{2} \mathrm{O}, \mathrm{Fe} / \mathrm{Mg}, \mathrm{Ga} / \mathrm{Al}, \mathrm{Zr}$, Ta, Sn, Y, REE and low CaO, Ba, Sr contents; the composition points to an 'A-type granite' melt. The rocks show negative Cs-, Sr-, Eu- and Ti- anomalies with incompatible element concentrations 2-3 times more than the upper continental crust (UCC). LREE is high $\left(\mathrm{La} / \mathrm{Yb} \sim 20\right.$ ) and HREE 20-30 times chondritic. $\delta^{18} \mathrm{O}_{\text {whole-rock }}$ varies between 4.4 and 7.8\%o (mean $5.87 \pm 1.26 \%$ o).

The Bijli melt is neither formed by fractionation of a basaltic magma, nor does it represent a fractionated crustal melt. It is shown that the mantle-derived high temperature basaltic komatiitic melts/high Mg basalts triggered crustal melting, and interacted predominantly with deep crust compositionally similar to the Average Archaean Granulite (AAG), and a shallower crustal component with low $\mathrm{CaO}$ and $\mathrm{Al}_{2} \mathrm{O}_{3}$ to give rise to the hybrid Bijli melts. Geochemical mass balance suggests that $\sim 30 \%$ partial melting of AAG under anhydrous condition, instead of the upper continental crust (UCC) including the Amgaon granitoid gneiss reported from the area, better matches the trace element concentrations in the rocks. The similar $\mathrm{Ta} / \mathrm{Th}$ of the rhyolites $(0.060)$ and average granulite (0.065) vs. UCC (0.13) also support a deep crustal protolith. Variable contributions of crust and mantle, and action of hydrothermal fluid are attributed for the spread in $\delta^{18} \mathrm{O}_{\text {whole-rock }}$ values. The fast eruption of high temperature $\left(\sim 900^{\circ} \mathrm{C}\right)$ rhyolitic melts suggests a rapid drop in pressure of melting related to decompression in an extensional setting.

\section{Introduction}

The petrogenesis of large volumes of rhyolites in association with basalts, but without rocks of intermediate composition is of considerable interest in igneous petrology for decades (e.g., Yoder 1973; Hildreth 1981; Cox 1988; Peccerillo et al 2003).
The unlikelihood of a wholly basaltic source for many voluminous potassic rhyolites is recognized time and again (e.g., Coleman and Walker 1992; Annen and Sparks 2002). The emerging idea based on isotopic, theoretical and experimental studies considers the important role of crust and/or juvenile contribution from the mantle in the generation

Keywords. Bimodal volcanism; high-silica melts; granulite melting; crust-mantle interaction; central India. 
of rhyolite to high-silica rhyolitic $\left(\mathrm{SiO}_{2} \geq 74 \mathrm{wt} \%\right)$ melts (e.g., Landenberger and Collins 1996; Patiño Douce 1999). The discovery of compositional similarities of the older Yellowstone silicic tuff to the interstitial glass of the Columbia River Plateau basalts (Nash et al 1996) is significant in this context. Evidence of chemical interaction between mafic magma and lower crustal material is well preserved in lower-crustal xenoliths (Downes 1993), and in exposed sections of the lower crust (e.g., the Ivrea Verbano zone, Sinigoi et al 1991). Yet, some workers believe that the traditional idea of basaltic magma fractionation is an effective mechanism for the origin of silicic melts (e.g., Garland et al 1995; Ayalew et al 2002). The other competing mechanism considers extensive fractional crystallization of the mantle-derived basaltic melt accompanied by assimilation of crustal components (e.g., Musselwhite et al 1989; Peccerillo et al 2003). In short, the nature of the involvement of both crust and mantle is where most controversy lies. The question is important, because if the only mantle contribution is heat, then the continental crust is largely recycled, but if mantle material is supplied, then it involves crustal growth. The issue perhaps assumes further significance if the silicic magmatism took place at or near $2.5 \mathrm{Ga}$, known to be a significant continental crust-building period. The petrogenetic study of the Bijli Rhyolite in the central Indian Craton, one of the most voluminous expressions of silicic volcanism in the Indian Precambrian Shield, is thus of topical relevance and would help in understanding the origin of similar rocks elsewhere.

This paper presents:

- new mineralogical and bulk chemical (major and trace elements) data of the Bijli Rhyolite,

- evaluation of its geochemical characteristics and

- important constraints for the genesis of such high silica melts including relative roles of crust and mantle and the nature of the protoliths.

Our recently published oxygen isotope data (Sensarma et al 2004) are also used for the purpose. The regional significance of this silicic volcanic activity is discussed at the end of the paper.

\section{Geological setting}

The Precambrian terrain in the central Indian Shield is divided into Northern Crustal Province (NCP) and the Southern Crustal Province (SCP) separated by a ENE-WSW trending belt referred to as the Central Indian Tectonic Zone (CITZ) (Roy et al 2000 and references therein). The SCP comprises a collage of N-S trending low-grade volcanic-sedimentary litho-stratigraphic units including the Dongargarh volcanic-sedimentary succession (Dongargarh Group) (figure 1). This group of rocks occurs in a linear belt in parts of Bhandara district of Maharashtra and Rajnandgaon district of Chattisgarh, and is southerly extended in the Bastar district of Chattisgarh. The Palaeoproterozoic (2.2-2.5 Ga) Dongargarh Group is weakly folded into a synclinal structure (Sitagota Syncline), and is intruded by a post-tectonic granite pluton (Dongargarh Granite) (Sarkar 1957-58; Sensarma 2001; Sensarma and Mukhopadhyay 2003) (table 1). Both felsic and mafic volcanic rocks are abundantly present in a bimodal distribution within the Dongargarh Group as demonstrated in the $\mathrm{SiO}_{2}$ vs. $\mathrm{Mg}$-number plot (figure 2), and are broadly contemporaneous to each other (Sensarma 2001). The silicic volcanic unit (Bijli Rhyolite) occurs at the base of the Dongargarh Group, and represents the first major magmatic activity in the belt. The overlying mafic volcanic rocks (Munro-type basaltic komatiite/high $\mathrm{Mg}$ basalts - tholeiite assemblages) of the Pitepani and Sitagota volcanic units are products of pulsatory eruptions of mantle plume origin (Sensarma 2001; Sensarma and Mukhopadhyay 2003). The Dongargarh Group of rocks is affected by low-grade green-schist facies metamorphism.

The Bijli Rhyolite is a $\sim 4.5 \mathrm{~km}$ thick and voluminous (>8000 cubic $\mathrm{km}$ ) particle-enriched fragmental deposit of pyroclastic origin, and principally exposed on the western limb of the Sitagota Syncline. It comprises several pyroclastic facies including ignimbrite, rheo-ignimbrite, breccia and breccio-conglomerate deposits (Sensarma 2001; Sensarma and Mukhopadhyay 2003). The rocks have variable concentration of crystals, vitric particles (shards, collapsed pumice, glassy fragments) and lithic fragments. The rocks show a N-S trending foliation with steep dip $\left(\sim 60^{\circ}\right)$ parallel to the regional schistosity. The primary flow layers are recognized on the weathered surface at a few places as rib like structures that cut across the regional foliation at a low angle $\left(15^{\circ}-20^{\circ}\right)$. The Bijli Rhyolite yielded $\mathrm{Rb}-\mathrm{Sr}$ whole rock isochron ages of $2180 \pm 25 \mathrm{Ma}$ $(\mathrm{ISR}=0.70571 \pm 0.0015)$ (Sarkar et al 1981) and $2503 \pm 35 \mathrm{Ma} \quad($ ISR $=0.7035 \pm 0.0017) \quad$ (Krishnamurthy et al 1990). Recent Rb-Sr whole rock isochron ages determined by Dr. K Gopalan and his associates at N.G.R.I., Hyderabad, (personal communication) from the rhyolite samples collected by the present authors suggest an age of $2089 \pm 29 \mathrm{Ma}$. The Rb-Sr whole rock isochron ages for the intrusive Dongargarh Granite is $2270 \pm 90 \mathrm{Ma}$ (Sarkar et al 1981) and $2465 \pm 22 \mathrm{Ma}$ $(\mathrm{ISR}=0.7010 \pm 0.0042) \quad$ (Krishnamurthy et al 


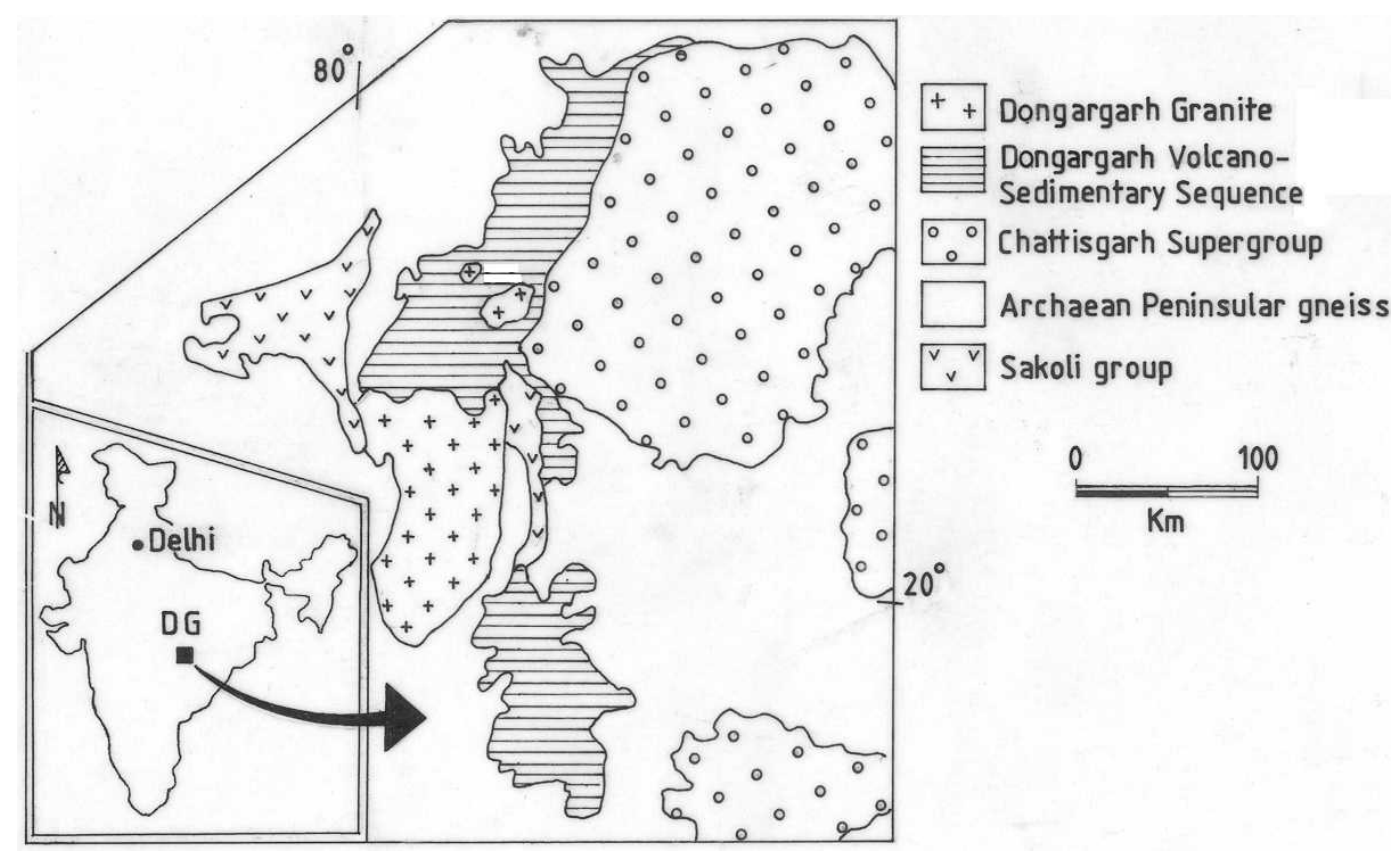

Figure 1. Location of the Dongargarh volcano-sedimentary sequence (Dongargarh Group) in the central Indian Craton. Map of India is shown in the inset.

Table 1. Litho-stratigraphic succession in the Dongargarh Belt, central India (Sensarma 2001; Sensarma and Mukhopadhyay 2003). The principal lithology of the units is shown within corresponding paranthesis.

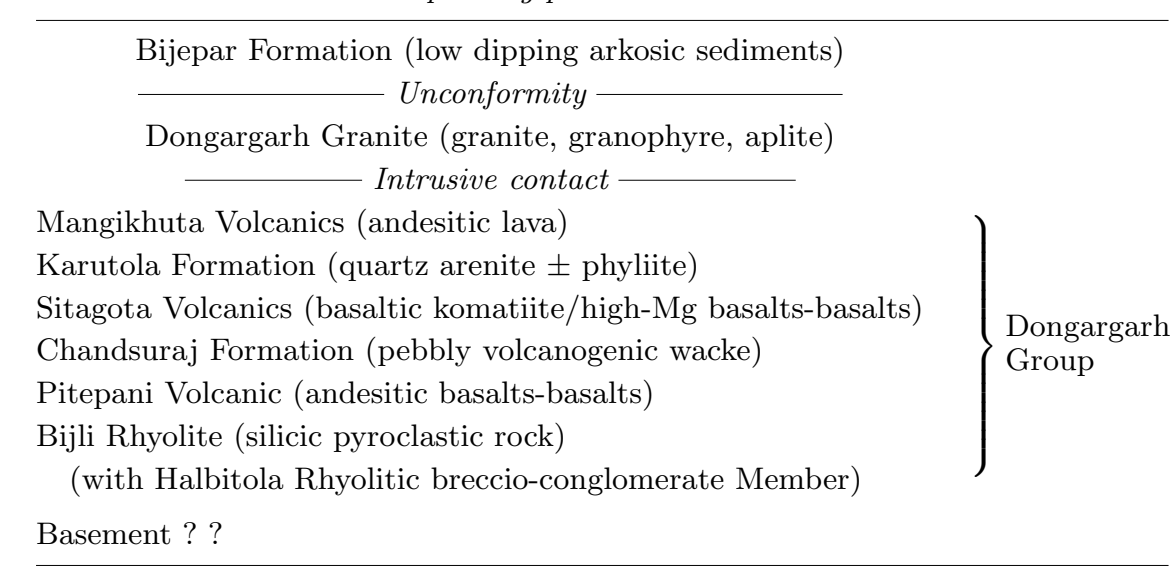

1990). The geochemical investigations of the Bijli Rhyolite include those by Sarkar et al (1994); Neogi et al (1996); Gangopadhyay and Roy (1997); Sensarma (2001). The petrogenetic aspects are discussed in Divakara Rao et al (2000).

The Munro-type komatiitic rocks are believed to occur at or near the Archaean-Proterozoic transition (Arndt 1994). Similarly, the presence of near contemporaneous Munro-type basaltic komattitic melts to the Bijli Rhyolite in the area, and the $\mathrm{Rb} / \mathrm{Sr}$ whole rock age of the Bijli Rhyolite suggest a palaeoproterozoic age $(\sim 2.5 \mathrm{Ga})$ for the Bijli Rhyolite.

\section{Analytical procedures and data base}

\subsection{Analytical procedures}

Aphanitic to ultrafine cherty samples with/without sparse crystals and free from effects of alteration, amygdules, veins and fractures have been given preference for chemical analysis, as these samples are likely to represent approximate bulk liquid composition. Most of the samples so chosen are of welded to extremely welded ignimbrite variety. The samples were collected near Salekasa $\left(21^{\circ} 10^{\prime}\right.$ : $\left.80^{\circ} 29^{\prime}\right)$, Makkatola $\left(21^{\circ} 15^{\prime}: 86^{\circ} 26 \frac{1}{2}^{\prime}\right)$, and further south near Deori in the Survey of India sheet no. 


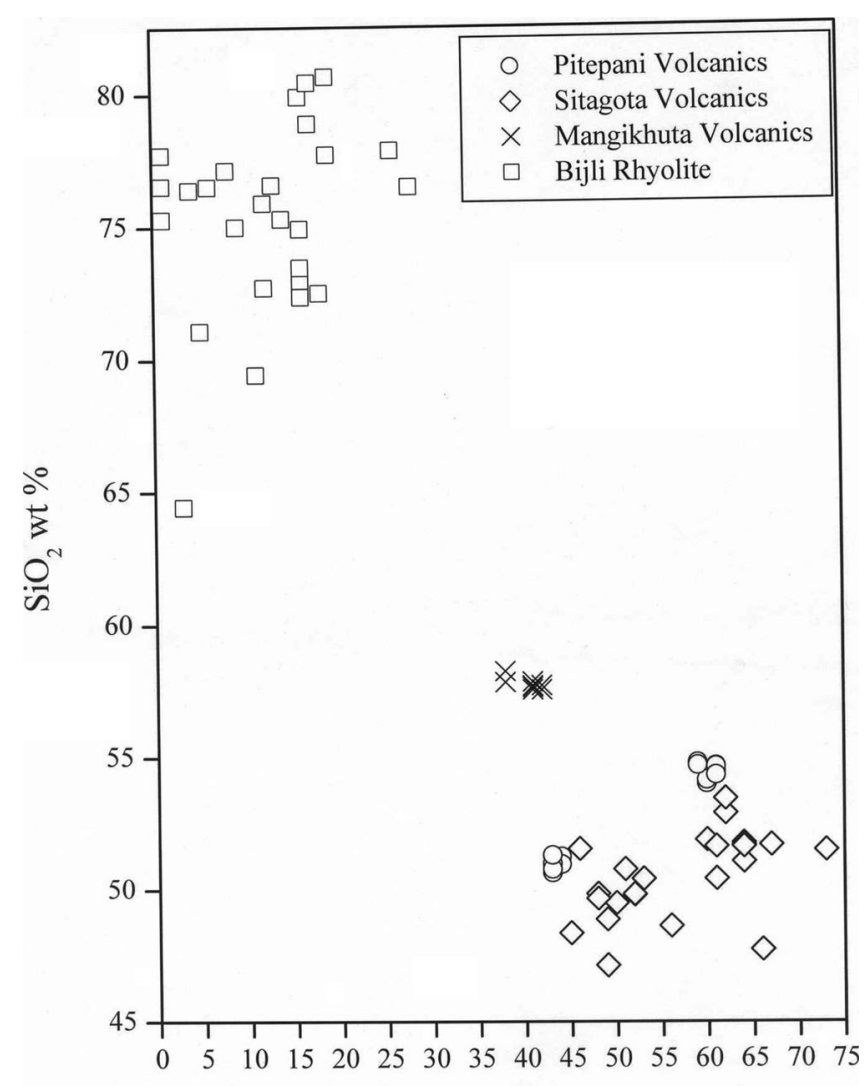

Mg-number

Figure 2. $\mathrm{SiO}_{2}-\mathrm{Mg}$ number plot showing bimodal character of the volcanic units in the Dongargarh Group.

$64 \mathrm{C} / 8$. The analytical work were mostly carried out at the Institut für Mineralogie und Geochemie, Universität $\mathrm{Zu}$ Köln, Germany and the Activation Laboratory Limited, USA. Some additional analyses were done at the School of Environmental Sciences, Jawharlal Nehru University (JNU), New Delhi and Geological Survey of India (GSI), Calcutta.

At the Universität Zu Köln, major and selected trace elements concentrations ( $\mathrm{Rb}, \mathrm{Sr}, \mathrm{Zr}, \mathrm{Ba}, \mathrm{Y}$, $\mathrm{Ni}, \mathrm{Cr}, \mathrm{Co}, \mathrm{Sc}, \mathrm{V}, \mathrm{Zn}$ ) were determined by a Philips PW 2400 XRF machine using fused glass discs. For trace elements, INAA method was used. The powdered samples were irradiated in the carrousel of the TRIGA reactor of the Universität Mainz, and subsequently counted on large Ge-detectors at the Institut für Mineralogie und Geochemie, Universität $\mathrm{Zu}$ Köln. Based on extensive comparison with standard rocks, the accuracy of the XRF data is estimated to be below $3 \%$. For INAA, accuracies are indicated in the respective table. Details of analytical procedures followed, and the interlaboratory comparison on accuracy of the XRF and INAA methods applied here are available in Sensarma et al (2002).

Some major and trace element data were generated at the Activation Laboratory Limited, USA, by XRF and ICP-MS methods using international standards, through the courtesy of Professor P H Reitan of the University at Buffalo. At JNU, major and trace element analyses were performed on a Labtam ICP-AES using international and in house standards. Silica was analyzed by colorimeter following the method of Shapiro and Brannock (1962). REE determination was done by column separation, as described in detail by Giritharan and Rajamani (1998). At GSI, major element concentrations of few samples were determined by XRF method with fused pallets using both in house and international standards. Data generated in these laboratories are in good agreement within the limits of uncertainty of the methods $(10-15 \%)$.

Electron microprobe analyses (EPMA) of feldspar were performed with a JEOL electron microprobe (JXA-8900) at the same institute in Köln. An acceleration voltage of $20 \mathrm{kV}$ and a beam current of $20 \mathrm{nA}$ were used. A set of natural minerals (for $\mathrm{Si}, \mathrm{Ca}, \mathrm{Na}, \mathrm{K}$ ) and synthetic oxides (for $\mathrm{Mg}, \mathrm{Fe}, \mathrm{Al}, \mathrm{Ti}$ ) were used for standardization.

The bulk analyses are supplemented with oxygen isotope analyses of whole rock and mineral separates (phenocrysts) of selected samples (Sensarma et al 2004). The analyses were done at the Universität Bonn, Germany on 8-10 aliquotes of whole rock powders using a modified (Clayton and Mayeda 1963) type extraction line. Purified F2 gas (Asprey 1976) was used to liberate oxygen, which was then converted to $\mathrm{CO}_{2}$ and measured on SIRA-9 mass spectometer (VG Instruments). For mineral analyses, quartz and feldspar phenocrysts were handpicked and cleaned in warm dilute HF to remove any glass, carbonate and other impurities. These analyses were also replicated.

\subsection{Data base}

EPMA data of feldspar is presented in table 2. The XRF and ICP data for major and selected trace elements are shown in table 3. Selected trace element data (ICP and INAA) are presented in table 4. Oxygen isotope data for both whole rock and phenocrysts (quartz and feldspar) are listed in table 5 .

In order to develop a unified petrogenetic model for such a huge volume of magmatic deposit, we have assembled major and trace element data $(n=85)$ from the literature (e.g., Neogi et al 1996; Gangopadhyay and Roy 1997; Divakara Rao et al 2000; Sensarma et al 2002) representing different parts of the unit including the Kotri belt in Bastar district (e.g., Shivkumar et al 2003). The published data are in reasonable agreement with the new data presented here. 


\section{Petrography and mineralogy}

Patchy alteration, devitrification, low-grade metamorphism and deformation have influenced the petrographic character of the rocks. Yet, the Bijli Rhyolite can be recognized to be ill-sorted pyroclastic deposit in which crystals, vitric clasts (pumice, shards, collapsed vitric fragments) and lithic particles occur in a fine-grained fragmental to microfragmental matrix of quartz-feldspar-sericitechlorite-iron-oxide \pm calcite assemblage. Crystalto crystal-vitric tuff is the dominant petrographic variety. The crystals are quatrz and feldspar, the latter being mostly K-feldspar. Framework quartz is anhedral to euhedral with frequent embayed margins. Clots of biotite, veinlets of quartz and calcite are occasionally present. Zircon, Fe-oxide particles are common accessories. Quartz-kfeldspar-plagioclase-orthopyroxene-clinopyroxeneilmenite-apatite represents the normative mineralogy. Lithic fragments are mostly of cognate type, devitrified and altered. Vitroclastic texture is common, with development of eutaxitic fabric in the welded varieties. The petrographic details of the rocks are discussed elsewhere (Sensarma 2001; Sensarma and Mukhopadhyay (in preparation)).

More than $70 \%$ of the phenocrysts in the Bijli Rhyolite are feldspars. Microprobe analyses of feldspars carried out on a number of samples show feldspar phenocrysts to be mostly of alkali feldspar, often with albite-orthoclase solid solutions or intergrowths. The composition of feldspar is presented in table 2. K-feldspar $\left(\mathrm{Or}_{100}-\mathrm{Or}_{71.7} \mathrm{Ab}_{25.2}\right)$ and albite $\left(\mathrm{Or}_{0.4} \mathrm{Ab}_{99.4}-\mathrm{Or}_{5.0} \mathrm{Ab}_{94.3}\right)$ constitute the main population, with subordinate anorthoclase $\left(\mathrm{Or}_{40.8} \mathrm{Ab}_{59.2}-\mathrm{Or}_{14.7} \mathrm{Ab}_{85.2}\right)$. Abundance of K-rich feldspar in the rocks (table 2) suggests K-rich character for the bulk liquid. Potassic rim around albite is also present.

\section{Geochemistry}

\subsection{Evaluation of post-crystallization alteration}

Alteration, low-grade metamorphism, devitrification, deformation have probably affected the chemistry of the original rocks. It is, therefore, important to evaluate the extent to which the chemical data of the Bijli Rhyolite represent the primary chemistry of the melts. Values of LOI, considered to be indicators of aqueous alteration of volcanic rocks, though low $(<2 \mathrm{wt} \%)$ in the analyzed samples, grossly maintain a positive relation with similarly low Cs concentration (figure 3 ). This may be attributed to preferential Cs mobilizaion during interaction with aqueous fluids (e.g.,
Rudnick and Presper 1990). The relatively immobile refractory lithophile major elements like $\mathrm{Al}$, $\mathrm{Ti}$ and to some extent $\mathrm{Ca}$ in the rocks, however, show systematic patterns in different variation diagrams (see later). K/Rb ratio (200-300) of the rocks is not far from typical igneous rock values ( 250) (Rudnick et al 1985). K/Ba and $\mathrm{Rb} / \mathrm{Sr}$ ratios show generally consistent pattern when plotted against silica (figures 4 and 5). Some rocks (e.g., Shivkumar et al 2003), however, have consistently higher $\mathrm{Rb} / \mathrm{Sr}$ values by about 3 times from rest of the data irrespective of silica concentration, probably implying original ratios. Five samples have higher but inconsistent $\mathrm{K} / \mathrm{Ba}$ values with respect to other samples signifying Ba mobility for these samples (figure 5). Th/U ratios in the rocks are not much variable. U generally shows greater mobility compared to $\mathrm{Th}$. Th/U ratios in many samples $(\sim 4)$ (figure 5 ) are close to that CI-chondrites (3.6), and consequently do not indicate any preferred mobilization of U compared to Th. On the other hand, a set of samples (e.g., Shivkumar et al 2003) show comparatively lower $\mathrm{Th} / \mathrm{U}(<2.5)$ (figure 5), but with no significant scatter on Th-U plot. These suggest generally unaltered characters of the suite, though not completely free from mobility of selected trace elements (e.g., Cs, Ba) during action of aqueous fluids. In addition, primitive upper mantle (PUM)normalized incompatible element and chondritenormalized REE patterns are regular implying that their concentrations and ratios in the samples, except those of Cs, reflect original magma characteristics. Since high field strength elements (HFSE) like $\mathrm{Ti}, \mathrm{Th}, \mathrm{Nb}, \mathrm{Ta}, \mathrm{Zr}, \mathrm{Hf}, \mathrm{Y}$ and REE generally remain immobile during various secondary processes, our petrogenetic interpretations mostly rely on these elements.

\subsection{Classification}

On a total Alkali-Silica diagram (Le Bas et al 1986) (figure 6), the samples mostly plot in the rhyolite field and are generally subalkaline in character. A few samples from Kotri area in the far southern part of the Dongargarh belt (e.g., Shivkumar et al 2003), however, plot as trachyte to trachy-andesite. The rocks (see in table 3 ) predominantly have very high silica content $\left(\mathrm{SiO}_{2} \mathrm{wt} \%>74 \mathrm{wt} \%\right)$, and thus can be termed high-silica rhyolite (cf., Pankhurst and Rapela 1995). These are high-K rocks $\left(\mathrm{K}_{2} \mathrm{O} \sim\right.$ $4-4.5 \mathrm{wt} \%)$ with total alkalies $\left(\mathrm{Na}_{2} \mathrm{O}+\mathrm{K}_{2} \mathrm{O}\right)$ up to $8-10 \mathrm{wt} \%$, but reaching up to $\sim 12 \mathrm{wt} \%$ especially in some samples from the Kotri area. The rocks are generally metaluminous (Sensarma 2001; this work), though some samples show peraluminous chemistry (Gangopadhyay and Roy 1997; Divakara Rao et al 2000; Shivkumar et al 2003). 


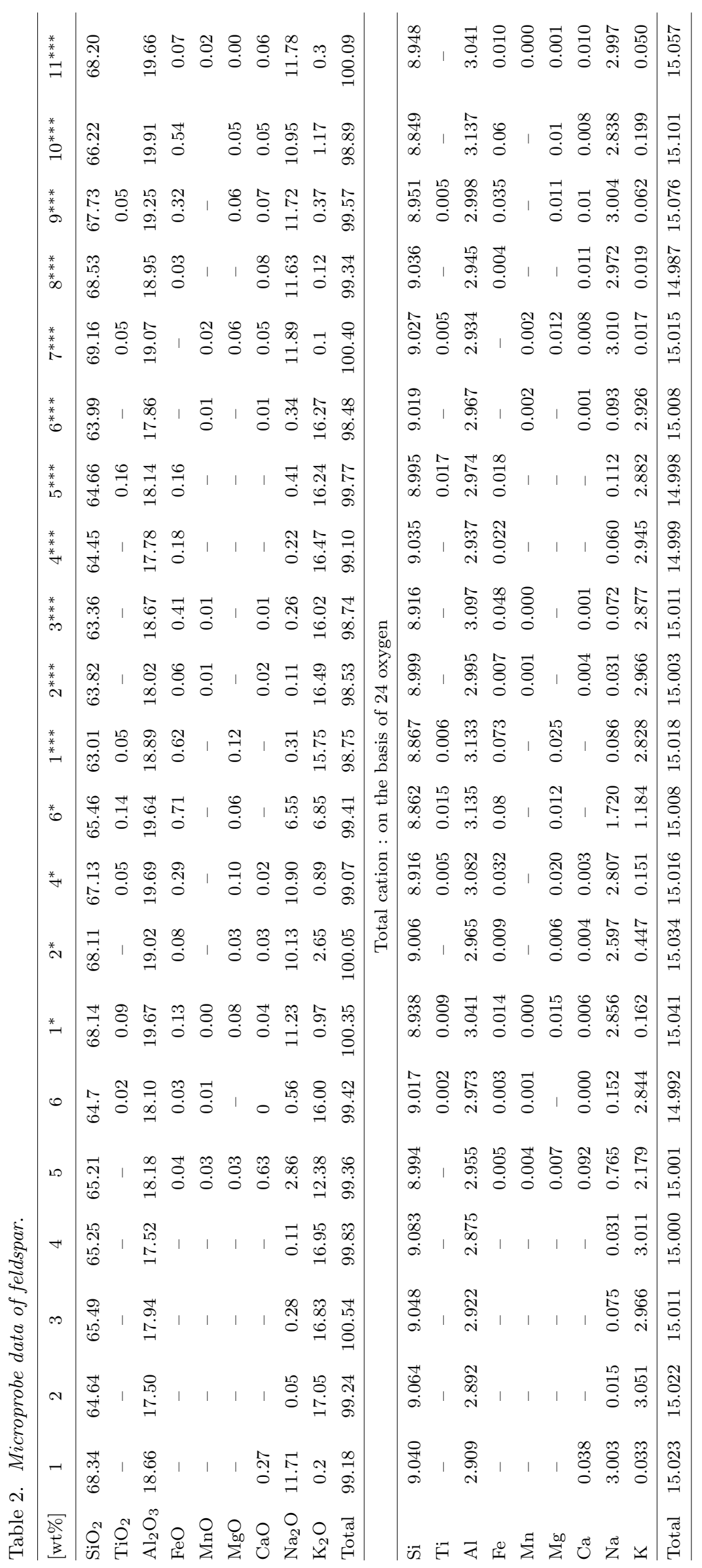




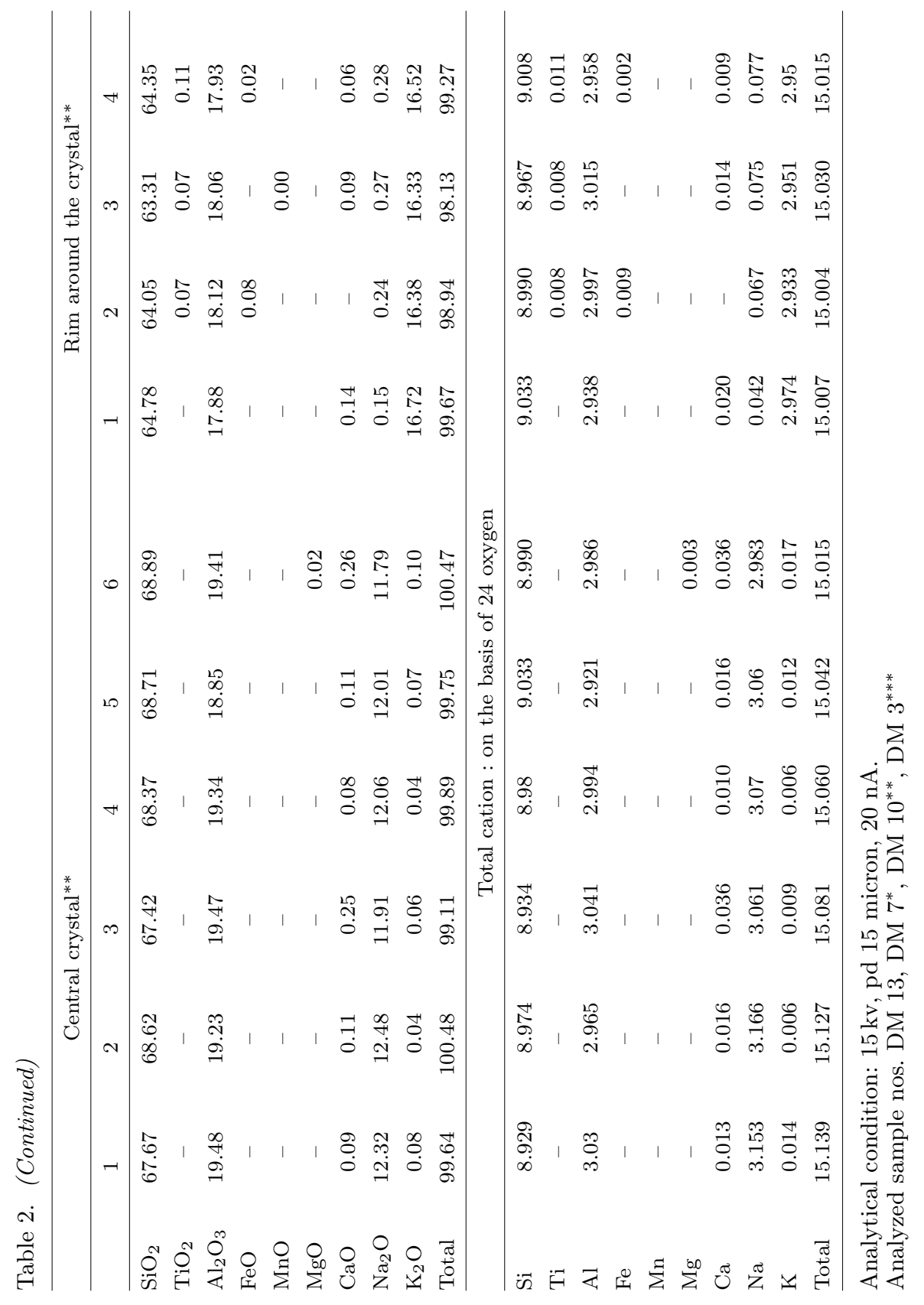




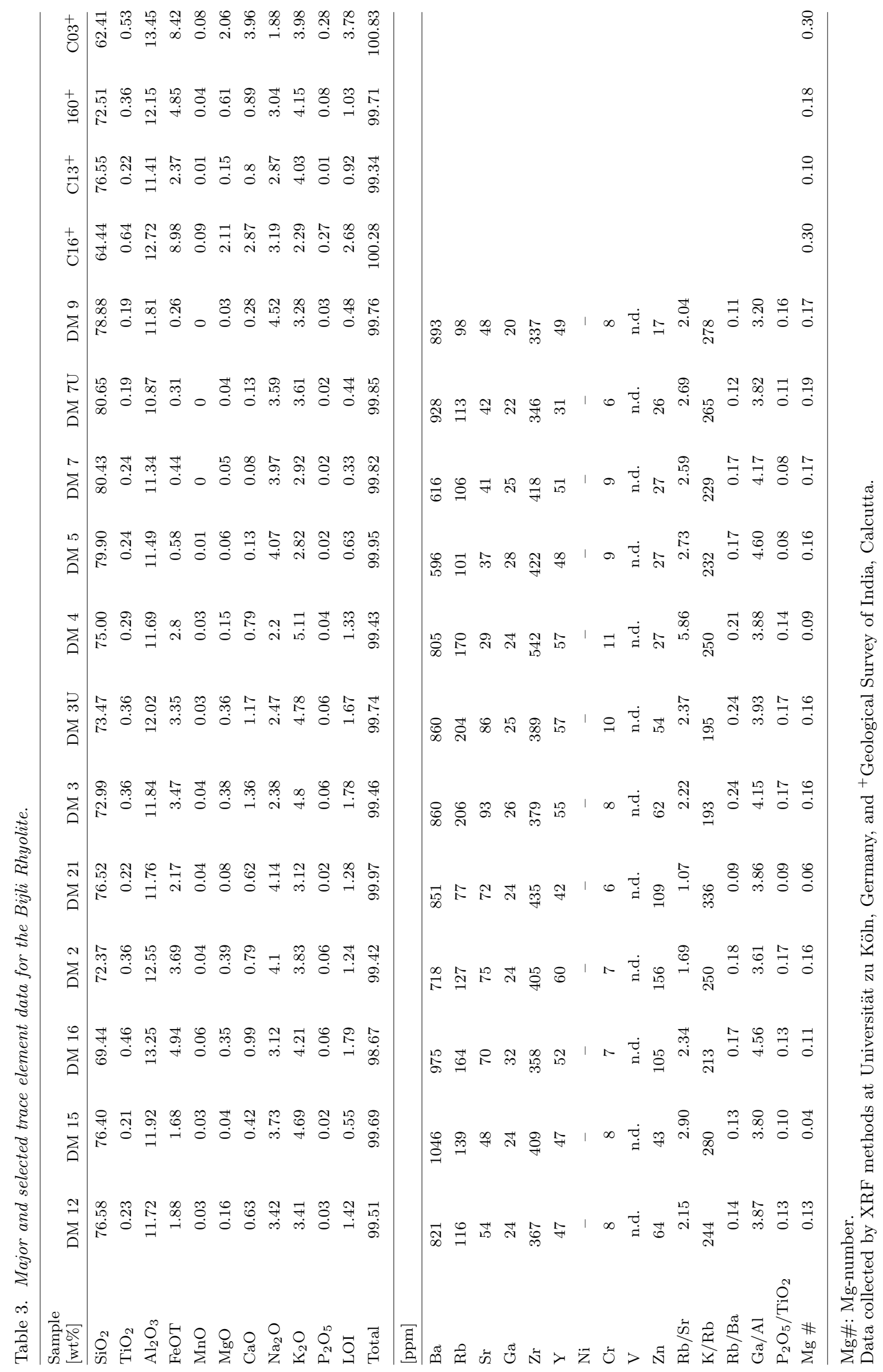




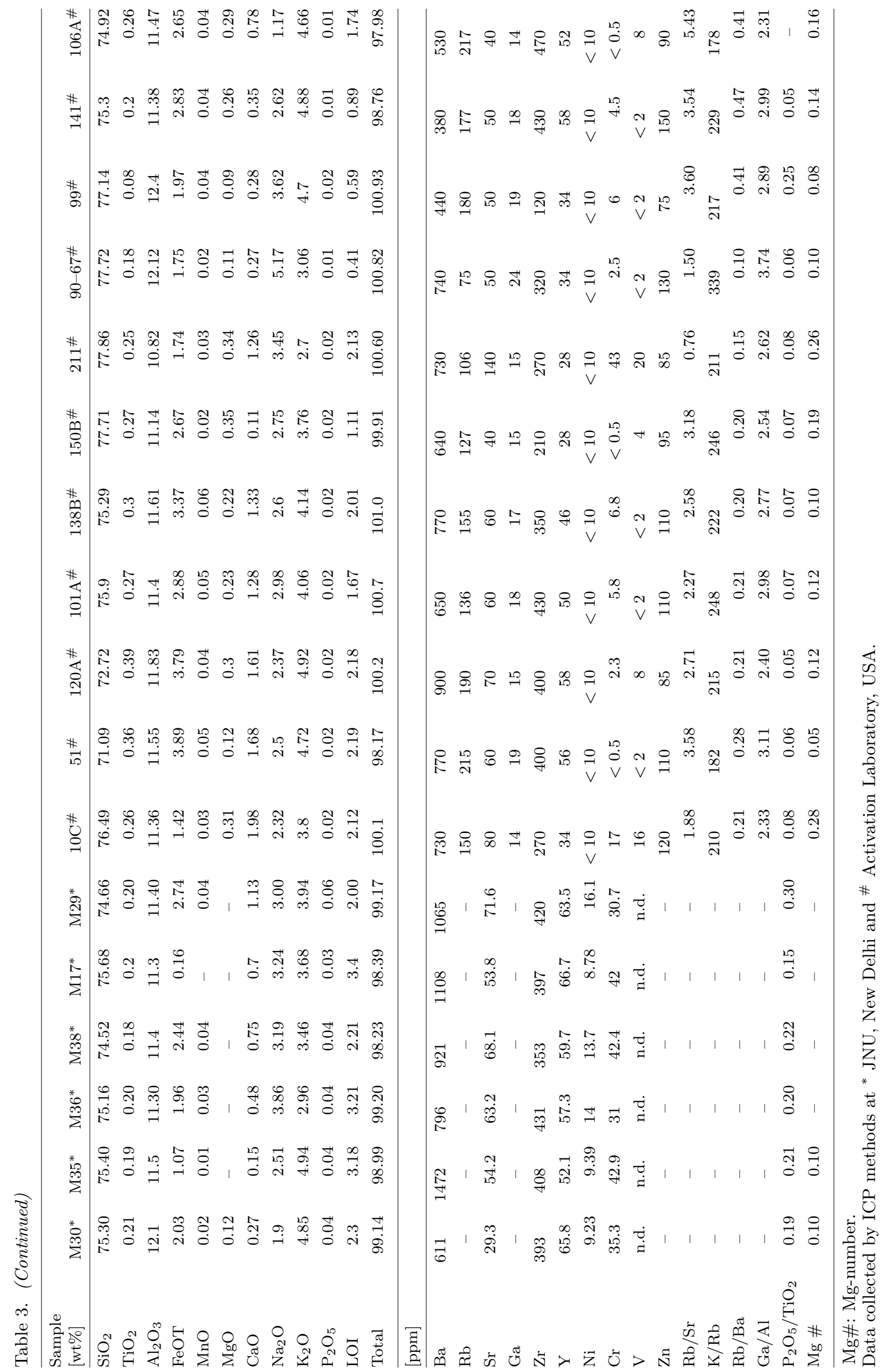




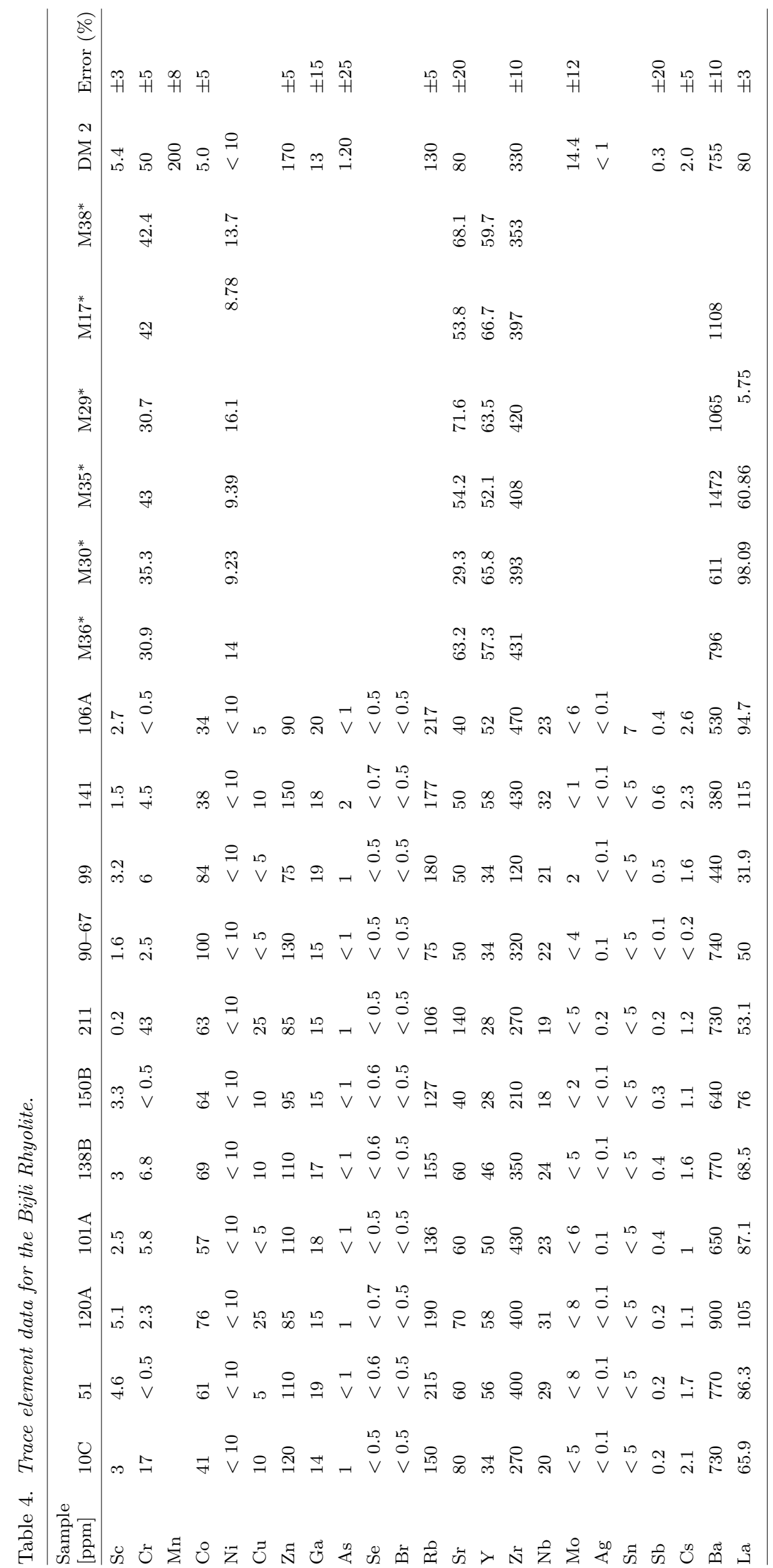




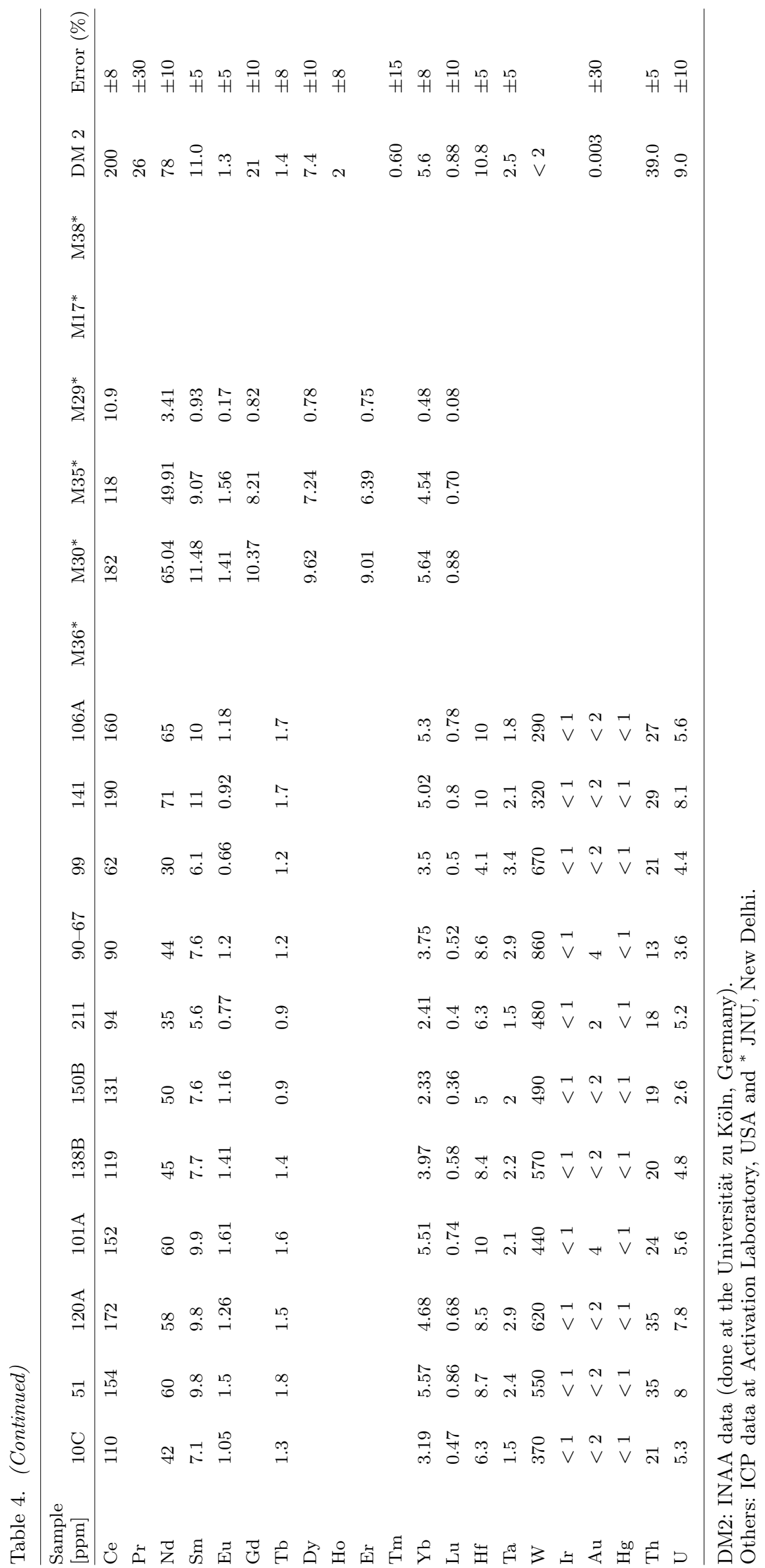


Table 5. O-isotope data for the Bijli Rhyolite.

\begin{tabular}{lcccc}
\hline Sample no. & DM 21 & DM 7 & DM 9 & DM 3 \\
\hline$\delta^{18} \mathrm{O}$ & & & & \\
$\quad$ (whole rock) & $7.8 \pm 0.1$ & $6.1 \pm 0.1$ & $5.2 \pm 0.1$ & $4.4 \pm 0.05$ \\
$\delta^{18} \mathrm{O}$ & & & & \\
$\quad$ (quartz) & $7.35 \pm 0.05$ & - & - & $4.5 \pm 0.1$ \\
$\delta^{18} \mathrm{O}$ & & & & \\
$\quad$ (feldspar) & $6.6 \pm 0.1$ & - & - & $4.2 \pm 0.1$ \\
\hline
\end{tabular}

The Bijli rocks have lower $\mathrm{Al}_{2} \mathrm{O}_{3}, \mathrm{MgO}, \mathrm{CaO}, \mathrm{Sr}$, and higher $\mathrm{FeO}, \mathrm{Zn}$ and HFSE (e.g., Zr, Nb, Ta, $\mathrm{Hf}, \mathrm{Ga}$ ) and REE concentrations (tables 3 and 4) in comparison to the fractionated I-type granites (felsic I-type granite of Whalen et al 1987) with similar $\mathrm{SiO}_{2}$ contents. High $\mathrm{SiO}_{2}, \mathrm{Na}_{2} \mathrm{O}+\mathrm{K}_{2} \mathrm{O}, \mathrm{Fe} / \mathrm{Mg}, \mathrm{Zr}$, $\mathrm{Ta}, \mathrm{Ga}, \mathrm{Sn}, \mathrm{Y}$, and REE (except Eu) contents and low $\mathrm{CaO}, \mathrm{Ba}$, Sr of the Bijli samples rather indicate similarity with a 'A-type granite' (cf. Collins et al 1982; Whalen et al 1987; Eby 1990). High $\mathrm{Ga} / \mathrm{Al}$ (average 3.71) of the Bijli rocks is also similar to A-type granites (see Whalen et al 1987; Eby 1990).

\subsection{Major elements}

The most striking feature of the Bijli Rhyolite samples is their high silica content and narrow range of major element compositions (table 3 ). The silica content varies from $64 \mathrm{wt} \%$ to $80.65 \mathrm{wt} \%$ with an average $\mathrm{SiO}_{2} \sim 75 \mathrm{wt} \%$. The different major oxides are plotted against $\mathrm{SiO}_{2} \mathrm{wt} \%$ (figure 7). The plots show that $\mathrm{TiO}_{2}$ wt $\%, \mathrm{FeO}$ wt $\%$ and $\mathrm{MgO}$ wt $\%$ decrease with increasing $\mathrm{SiO}_{2} \mathrm{wt} \%$. The data in $\mathrm{MgO}$ diagram plot along a curved trend, whereas $\mathrm{TiO}_{2}, \mathrm{FeO}_{\mathrm{t}}$ trends are practically linear. The scatter of data is larger for $\mathrm{Al}_{2} \mathrm{O}_{3}$ and $\mathrm{CaO}$ plots; the average $\mathrm{Al}_{2} \mathrm{O}_{3}$ content $(\sim 12 \mathrm{wt} \%)$ significantly less than in calc-alkaline rhyolite (>14 wt\%) (Philpotts 1990). A close study of $\mathrm{Al}_{2} \mathrm{O}_{3}$ plot, however, shows decrease in $\mathrm{Al}_{2} \mathrm{O}_{3}$ contents with increasing silica, but along two sub-parallel trends with an increase in $\mathrm{Al}_{2} \mathrm{O}_{3}$ contents at $\mathrm{SiO}_{2} \sim 76$ wt $\%$. A similar increase in $\mathrm{CaO}$ concentrations in the suite can also be detected at similar silica level $\left(\mathrm{SiO}_{2} \sim 76 \mathrm{wt} \%\right)$. The $\mathrm{K}_{2} \mathrm{O}$ content in the rocks is much higher than that of calc-alkaline rhyolites (Hess 1989, p 224). The $\mathrm{K}_{2} \mathrm{O} / \mathrm{Na}_{2} \mathrm{O}$ ratio of the rocks is 1.43 , with $\mathrm{K}_{2} \mathrm{O}$ and $\mathrm{Na}_{2} \mathrm{O}$ showing mutually negative relationship (figure 8). It is important to note here that concentrations of $\mathrm{K}_{2} \mathrm{O}$ and $\mathrm{Na}_{2} \mathrm{O}$ are clearly higher in Kotri samples than rest of the data, which is consistent with the presence of more alkali rich lava like trachyte and trachy-andesite there. The rise in $\mathrm{Al}_{2} \mathrm{O}_{3}$ and $\mathrm{CaO}$ contents at a particular silica value may be of significance, as discussed later.

\subsection{Trace elements}

Unlike major elements, trace element distributions in the rocks exhibit larger variations (tables $3 \&$ 4) (this work; Neogi et al 1996; Divakara Rao et al 2000; Sensarma 2001; Sensarma et al 2002). The rocks are enriched in incompatible elements like $\mathrm{K}, \mathrm{Ba}, \mathrm{Rb}$, Th, U, Ta, Zr, and LREE, and depleted in compatible elements like $\mathrm{Cr}(\sim 8 \mathrm{ppm})$, Sc $(<10 \mathrm{ppm})$ and Mn compared to the upper continental crust (UCC). When plotted against silica, certain incompatible element ratio like $\mathrm{K} / \mathrm{Rb}(200$ $400)$ and $\mathrm{Rb} / \mathrm{Sr}(1.5-6)$ in the suite varies within a small range (figure 4 ). $\mathrm{K} / \mathrm{Ba}$ ratios maintain constant value at 100 (figure 5), though a couple of samples show large scatter associated with occasional Ba mobilization during secondary processes, as discussed earlier. PUM (Primitive Upper Mantle of McDonough and Sun 1995) normalized plots for the incompatible elements (figure 9) show a pattern similar to that of Upper Continental Crust (UCC) of Taylor and McLennan (1985), but display overall enrichment by a factor of 2 to $3 \mathrm{com}-$ pared to the UCC. There are distinct negative Cs-, Sr-, Eu- and Ti-anomalies; Sr-anomaly being the most prominent. The negative Cs-anomaly is responsible for the very high $\mathrm{Rb} / \mathrm{Cs}$ ratios $(>100)$ of the rhyolites compared to $\mathrm{Rb} / \mathrm{Cs}$ (30) of the UCC. Thorium (Th) and Uranium (U) concentrations in the rocks are high (about 10 times) compared to the UCC. Th/U ratios in the rocks range between 1 and 7 against a crustal Th/U ratio $(\sim 4)$ (figure 5). The samples maintain crustal ratios of $\mathrm{Nb} / \mathrm{Ta}$ (11) (figure 10), and $\mathrm{Zr} / \mathrm{Hf}$ (35), but have low Ta/Th ( $\leq 0.06$ vs. 0.13$)$ compared to the UCC. $\mathrm{Zr} / \mathrm{Y}$ ratios in the Kotri samples vary by about two times (6-10) (figure 10). The REE abundances in the rocks are high. Chondrite normalized Rare Earth Elements (REE) patterns (figure 11) show that the samples have very steep LREE pattern with high $\mathrm{La} / \mathrm{Sm}(\sim 6.5)$ and $\mathrm{La} / \mathrm{Yb}(\sim 20)$ and very pronounced negative Eu-anomalies. HREE patterns show slightly negative trend $(\mathrm{Gd} / \mathrm{Yb} \sim 3)$ within the limits of analytical error with concentrations more than 20-30 times chondritic. The REE patterns are not parallel to one another, rather sometimes cross each other. Such crossing of REE patterns from presumably co-genetic lava is unique to high-silica rhyolites (Hess, 1989).

\subsection{Oxygen isotopes}

Oxygen isotope data for selected samples of the Bijli rhyolite rocks are presented in table 5 . Whole-rock data show an average value of $5.87 \pm$ $1.26 \%$ comparable to mantle value $(5.7 \pm 0.3 \%$ o $)$ (e.g., Rollinson 1993), though with a larger spread. Since large shifts in $\delta^{18} \mathrm{O}$ value can occur in vol- 


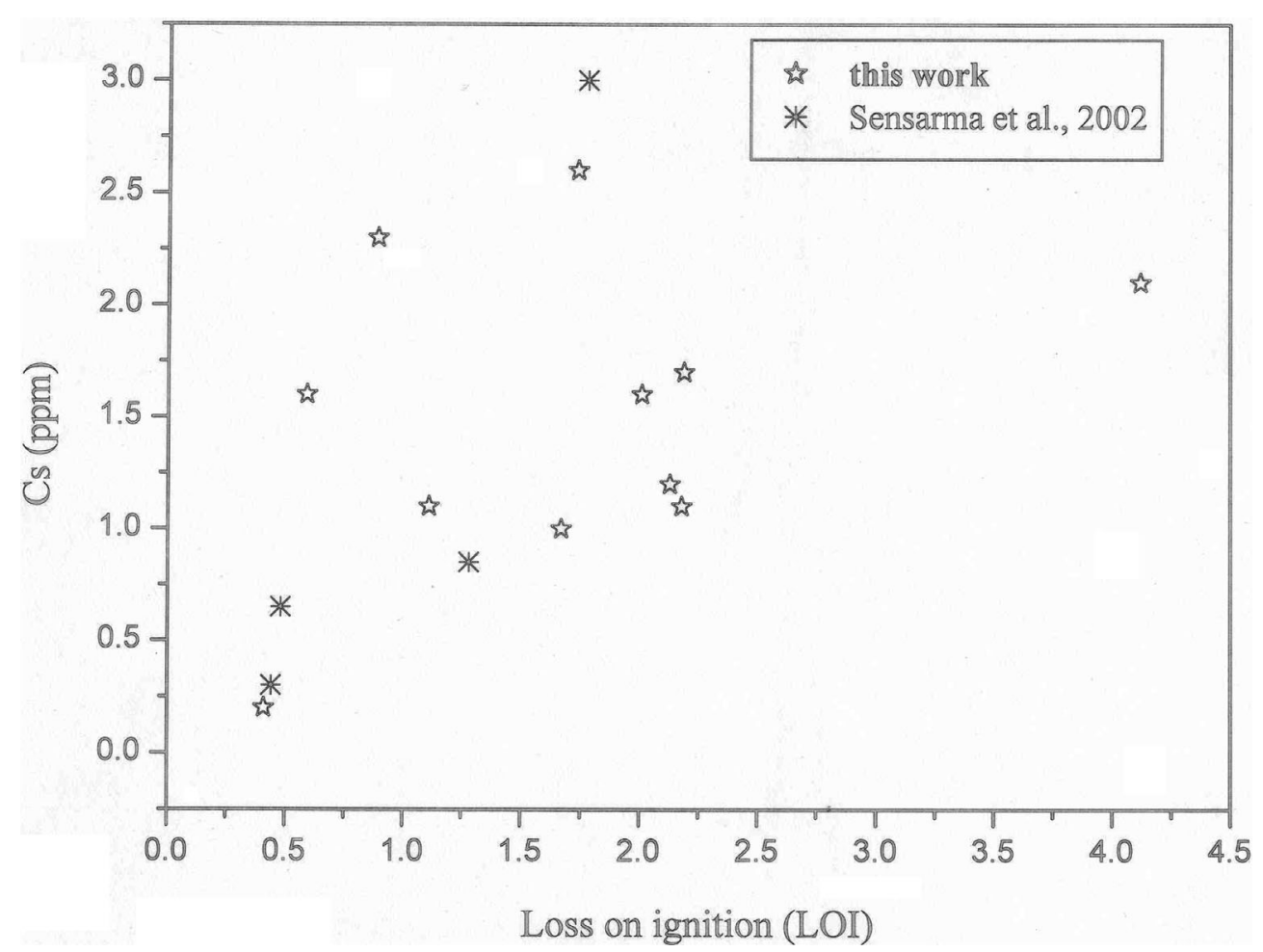

Figure 3. LOI (loss on ignition) vs. Cs (ppm) plot showing a general rise in Cs concentrations with increase in LOI in the Bijli Rhyolite.

canic rocks due to low temperature alteration processes, we also analyzed grains of quartz and K-feldspar phenocrysts from the same samples, which are likely to remain unaffected by alteration processes (Taylor 1980). We note that the $\delta^{18} \mathrm{O}$ value for whole rock and quartz separates for DM3 $(4.4 \pm 0.05 \%$ vs. $4.5 \pm 0.1 \% \circ)$ and DM21 (7.8 \pm $0.1 \%$ vs. $7.35 \pm 0.05 \%$ ) (table 5 ) are comparable.

This further confirms the generally unaltered character of our samples. However, as quartz must always be heavier than the corresponding whole rock value, slightly enriched DM $21_{\text {whole-rock }}$ value relative to its quartz may indicate some degree of

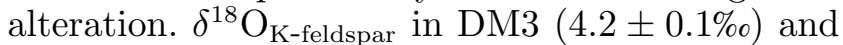
DM21 $(6.6 \pm 0.1 \%$ ) is lower than that of both quartz and whole rock (table 5), though the quartz-Kfeldspar fractionation between 0.8 (DM21) and 0.3 (DM3) is very close to values typical of fresh unaltered magmatic rocks.

\section{Thermometry}

Temperatures calculated from oxygen isotope fractionations (e.g., Hoffbauer et al 1994) suggest $880^{\circ} \mathrm{C}$ for DM21, a value close to solidus temperature of dry rhyolitic magmas (Nekvasil 1992); and a value of $1550^{\circ} \mathrm{C}$ for DM3, which is, however, by far too high. This might be connected to the unusual oxygen isotopic composition of
DM3. The whole-rock value of $4.4 \%$ o for this sample is too low even for any mantle derived melt (Taylor and Sheppard 1986), and thus could be indicative of fluid-rock exchange with a meteoric component. Any substantial exchange, however, would drive the feldspar isotopic composition to effect larger quartz-K-feldspar fractionation. The low values reported here therefore indeed represent low ${ }^{18} \mathrm{O}$ magma, and at the same time a strong indication of participation of deeper crustal component/mantle in the genesis of the Bijli Rhyolite.

The $\mathrm{Zr}$ solubility in our melts $(\sim 400 \mathrm{ppm})$ with a low cation ratio $((\mathrm{Na}+\mathrm{K}+2 \mathrm{Ca}) /(\mathrm{Si} \times \mathrm{Al})=0.03)$ (cf., Watson and Harrison 1983) indicate a temperature range of $860^{\circ}-930^{\circ} \mathrm{C}$. The $\mathrm{P}_{2} \mathrm{O}_{5^{-}}$(Harrison and Watson 1984) and Mg-themometers (see in Johannes and Holtz 1996) yield a similarly high temperature $\left(900^{\circ}-950^{\circ} \mathrm{C}\right.$ and $850^{\circ}-900^{\circ} \mathrm{C}$ respectively) for our rocks. One sample (C03) with higher $\mathrm{P}_{2} \mathrm{O}_{5}$ content $(0.28 \mathrm{wt} \%)$ at $\mathrm{SiO}_{2}(64.41 \mathrm{wt} \%)$ indicates even a higher temperature $\left(\sim 950^{\circ} \mathrm{C}\right)$. The high temperature $\left(\sim 900^{\circ} \mathrm{C}\right)$ for the Bijli melts as obtained by different thermometers is primary, because such a temperature is not attainable during low grade metamorphism of the green schist facies condition. Also, it is independent of pressure of melting or melts $\mathrm{H}_{2} \mathrm{O}$ contents. The presence of anorthoclase in the rocks also argues for high temperature Bijli melts. 

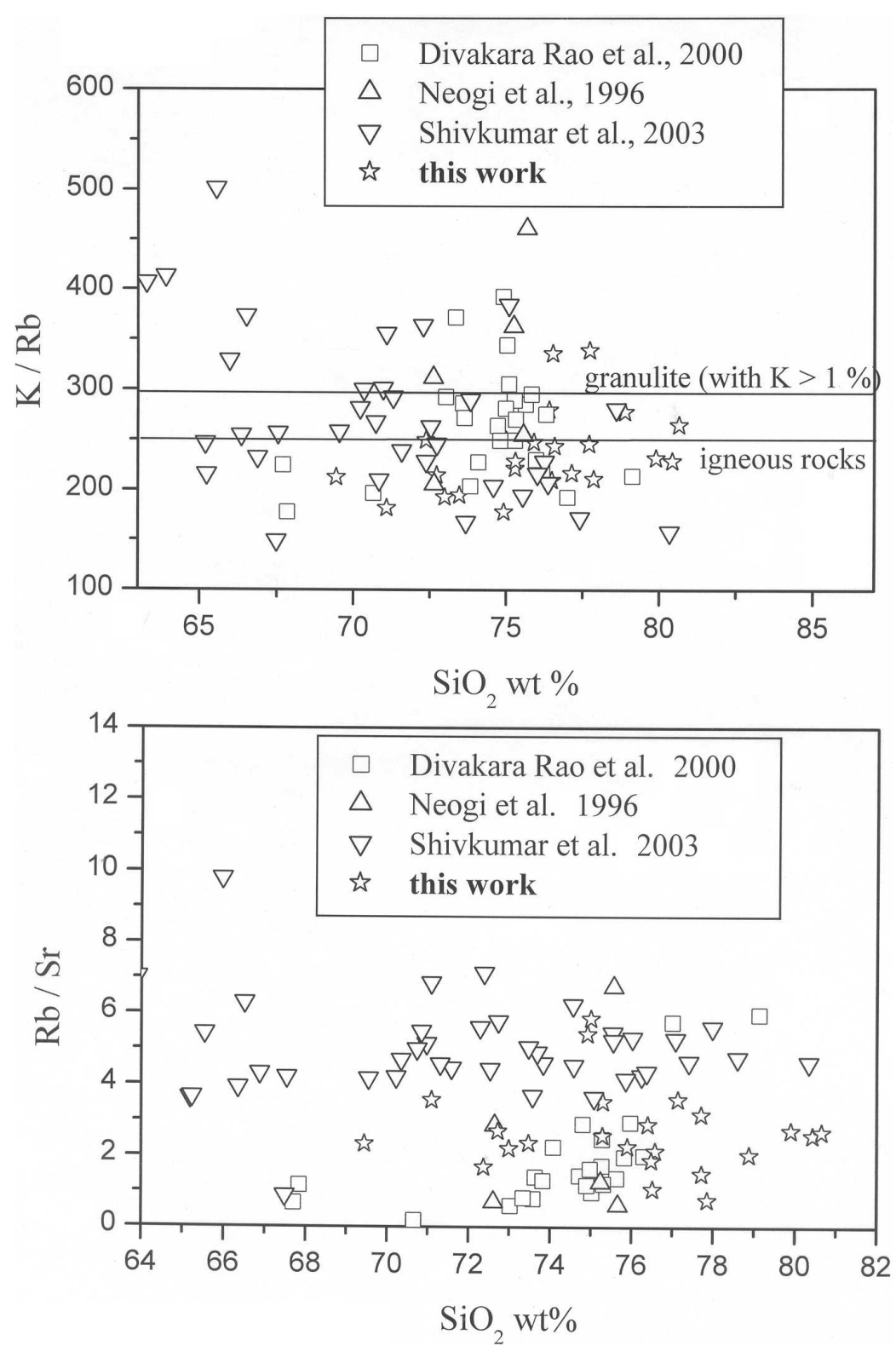

Figure 4. $\quad \mathrm{SiO}_{2}$ wt\% vs. K/Rb and $\mathrm{Rb} / \mathrm{Sr}$ plots. K/Rb (200-300) of the rocks are in the range of average igneous rocks. $\mathrm{Rb} / \mathrm{Sr}$ of the rocks vary by two to three times. Symbols are described in the legend. Note higher Rb/Sr values for the Kotri samples.

\section{Petrogenesis}

\subsection{Fractional crystallization of basaltic magma}

The trends in $\mathrm{SiO}_{2}-\mathrm{FeO}, \mathrm{SiO}_{2}-\mathrm{MgO}$ and $\mathrm{SiO}_{2}-\mathrm{TiO}_{2}$ plots show decrease in $\mathrm{FeO}, \mathrm{MgO}$ and $\mathrm{TiO}_{2}$ contents with silica in the bulk liquid (figure 7), which may indicate some sort of crystal-liquid fractionation process, e.g., fractional crystallization, partial melting and/or contamination. To test the fractional crystallization hypothesis, we adopted the 'lever rule' principle of Cox et al (1987), where it is possible to calculate graphically the way in which a liquid composition changes as a particular mineral is removed. On $\mathrm{SiO}_{2}-\mathrm{Al}_{2} \mathrm{O}_{3}$ plot (figure 12), fractionations of plagioclase-pyroxene seem possible, as the line joining pyroxene-plagioclase intersect the bulk compositional trend of the Bijli rocks. Plot of pyroxene along the bulk compositional trend in CaO- $\mathrm{SiO}_{2}$ plot (figure 12) also indicates involvement of pyroxene in the evolution of the Bijli melts. However, the proportions of pyroxene fractionation as per these plots do not tally with the negligible amount required by the $\mathrm{MgO}-\mathrm{CaO}$ plot (figure 12). So, the plots are not internally consistent to signify any role of pyroxene fractionation in the evolution of the Bijli melts. A similar conclusion can be drawn for ilmenite fractionation from $\mathrm{FeO}-\mathrm{TiO}_{2}$ 

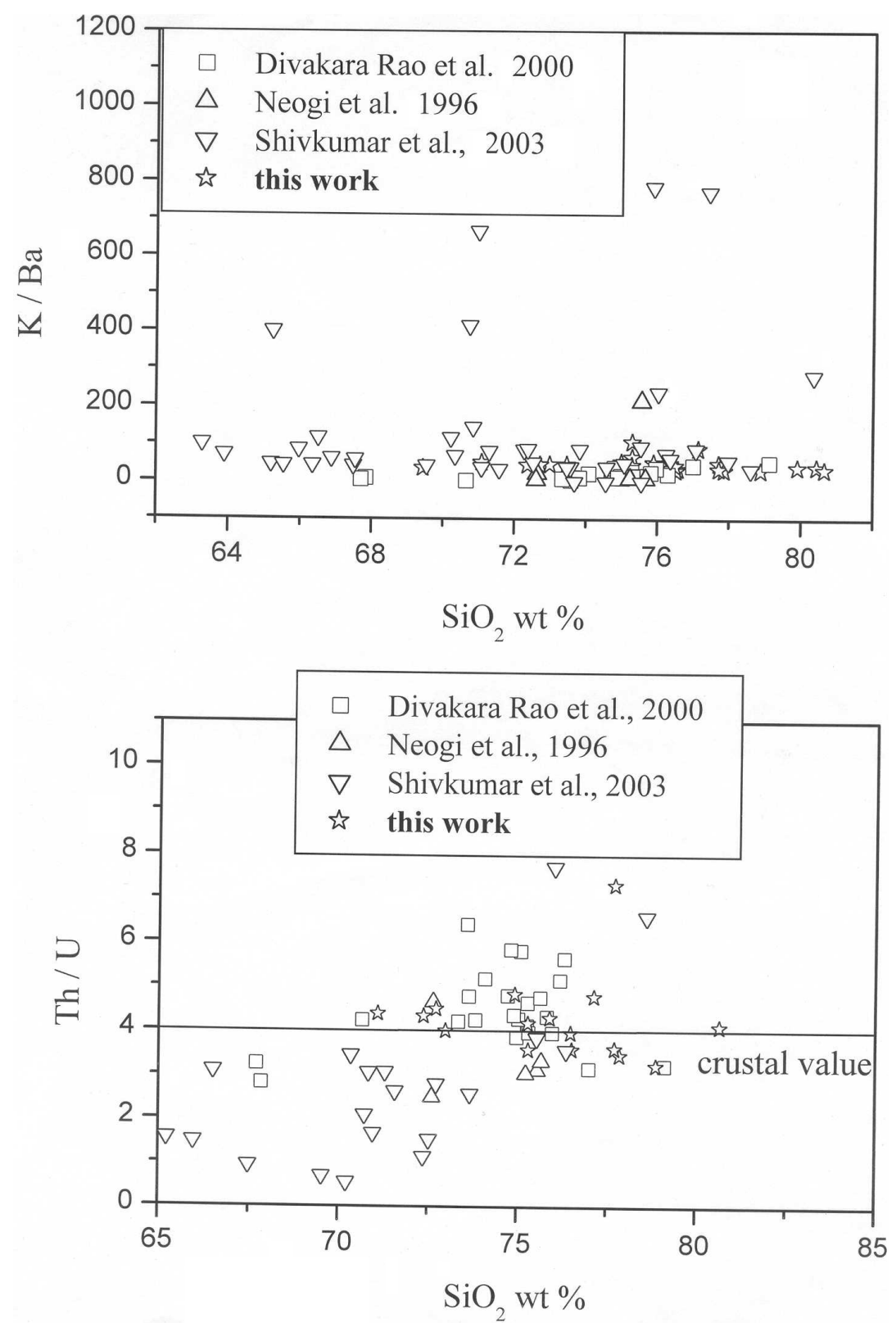

Figure 5. $\quad \mathrm{SiO}_{2}$ wt\% vs. $\mathrm{K} / \mathrm{Ba}$ and $\mathrm{Th} / \mathrm{U}$ plots. Note the constant $\mathrm{K} / \mathrm{Ba}(100)$ for the Bijli samples. Few samples with higher $\mathrm{K} / \mathrm{Ba}$ values indicate $\mathrm{Ba}$ mobilization. Th/U for many samples are at or near crustal value (4). Symbols are described in the legend. Note low $\mathrm{Th} / \mathrm{U}$ values for the Kotri samples.

and $\mathrm{CaO}-\mathrm{TiO}_{2}$ plots (figure 12). In the basaltic magma fractionation model, a large amount of basalt is needed, and it would produce only a small amount of derivative silicic melt contrary to what we have in Dongargarh. Also, continuous ranges of differentiated product of a basaltic magma like andesite, dacite, rhyodacite do not occur in spatial proximity to the rhyolite in the area. Rather, the Bijli Rhyolite and overlying basalts show clear presence of the 'Daly gap' (figure 2). We therefore do not see the possibility of a basaltic magma fractionation to be solely responsible for generation of the Bijli melts.
However, it is difficult to explain elevated concentrations of certain compatible elements (e.g., $\mathrm{Co}, \mathrm{Cr}$ ) in few rhyolite samples with high silica $\left(\mathrm{SiO}_{2}>75 \mathrm{wt} \%\right)$ and incompatible trace element (LILE, HFSE, LREE) contents (tables 3 and 4) without participation of mantle-derived melts. At the same time, the Bijli suite includes rocks with $\mathrm{SiO}_{2}$ contents of $65 \mathrm{wt} \%$ or less, that are not easily explained as pure crustal melts. The involvement of a mantle derived magma in the origin of the Bijli melts therefore still remains valid, but could be better known once we understand the role of crust in this scenario. 


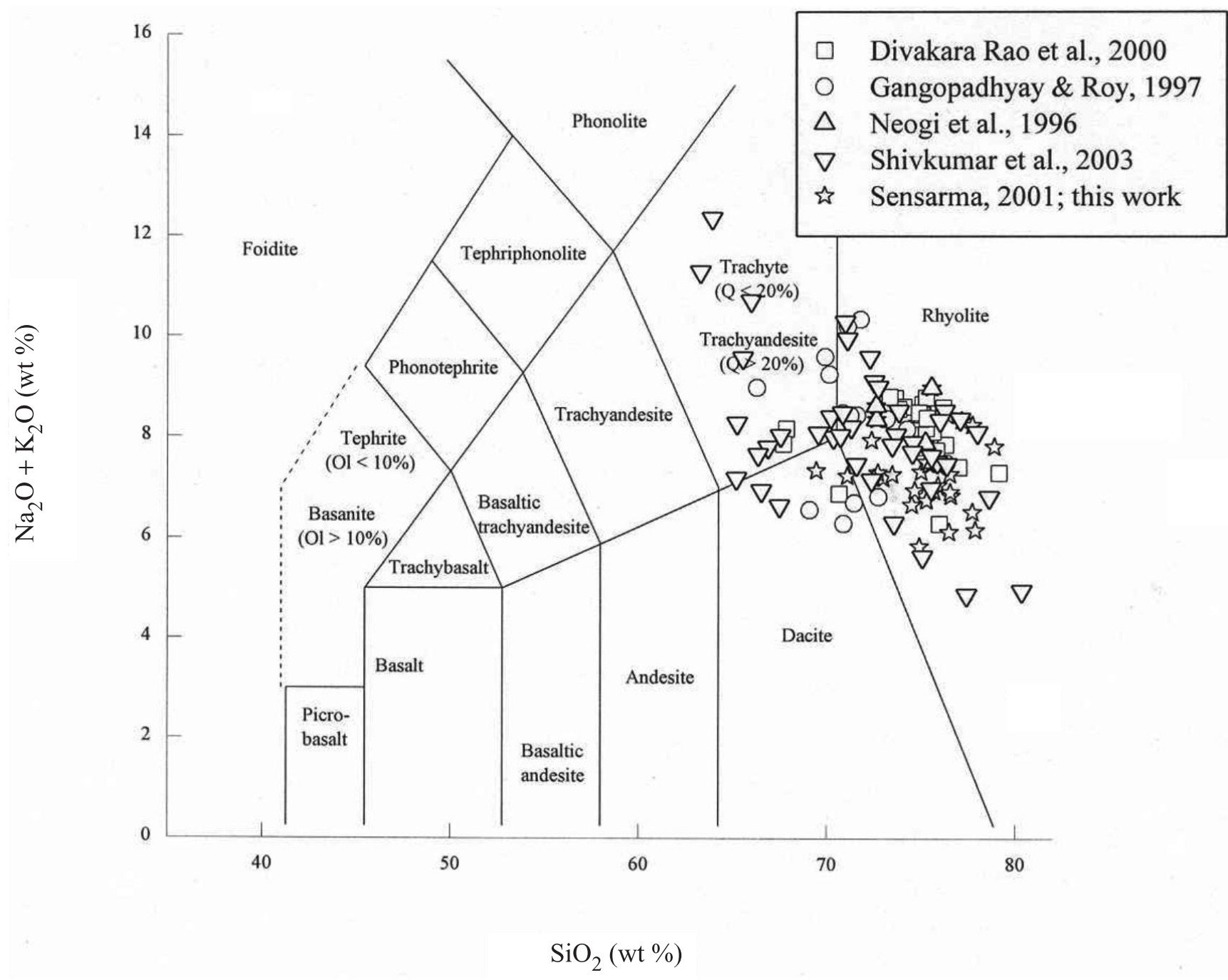

Figure 6. Plot of the Bijli Rhyolite samples on a total alkali-silica (TAS) diagram (after Le Bas et al 1986). Different symbols indicate different data sources, as shown in the legend.

\subsection{Crustal origin}

The possibility of crustal melting in the origin of the Bijli Rhyolite is certainly attractive as the presence of the silica gap is often considered as evidence in support of a partial melting model (Bellieni et al 1986). Comparable ${ }^{87} \mathrm{Sr} /{ }^{86} \mathrm{Sr}$ ratios of the Bijli Rhyolite, $0.70305 \pm 0.0017$ (Krishnamurthy et al 1990) and $0.7057 \pm 0.0015$ (Sarkar et al 1981), to that of the crustal value $(\sim 0.703)$ at $\sim 2.5 \mathrm{Ga}$ (see Philpotts, 1990, p 434) may indicate a crustal origin for these rocks. The high alkali contents and the similarity in trace element distribution patterns of the samples and that of UCC (figure 9) also probably point to a crustal derivation. Crustal anatexis requires anomalously high temperatures within the continental crust through localized heat source, and/or by decompression of heated rock during crustal thinning (Thompson 1999). The potential heat source could be the high temperature mantle- derived melts (cf. Clemens and Vielzeuf 1987; Huppert and Sparks 1988), which erupted subsequently as basaltic komatiite/high-Mg basalts in the Dongargarh succession (see above). It is not clear whether the fractionation of crustal partial melts was important in the evolution of this high silica melts, as suggested for the Chon Aike rhyolites in Patagonia (Pankhurst and Rapela 1995). We evaluate below the role of fractional crystallization of crustal partial melt, and then examine the possible crustal source(s) and degree of melting that could have given rise to the Bijli melts.

\section{2a Fractionation of a crustal melt}

\section{Feldspar}

On $\mathrm{SiO}_{2}-\mathrm{Al}_{2} \mathrm{O}_{3}$ and $\mathrm{MgO}-\mathrm{CaO}$ diagrams (figure 12), the join between potential fractionating phases from a silicic melt, such as K-feldspar and plagio- 

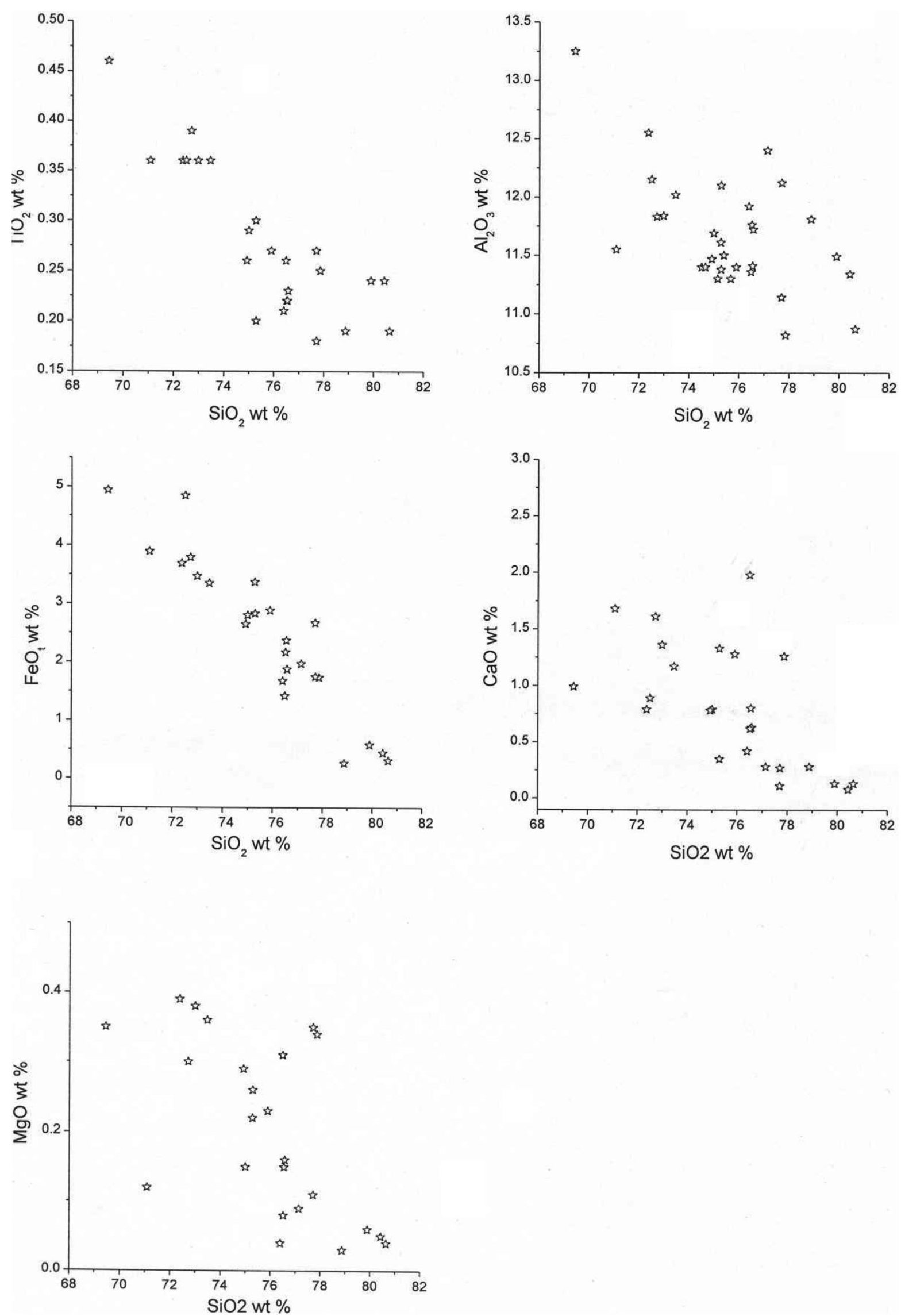

Figure 7. The Bijli rocks show decrease in major oxide contents with increasing $\mathrm{SiO}_{2} \mathrm{wt} \%$. The trends in $\mathrm{MgO} \mathrm{FeO}$, $\mathrm{TiO}_{2}$ plots are linear. $\mathrm{Al}_{2} \mathrm{O}_{3}$ plot shows two sub-parallel trends with rise in $\mathrm{Al}_{2} \mathrm{O}_{3}$ and $\mathrm{CaO}$ contents at $\mathrm{SiO}_{2} \sim 76$ wt\%. 


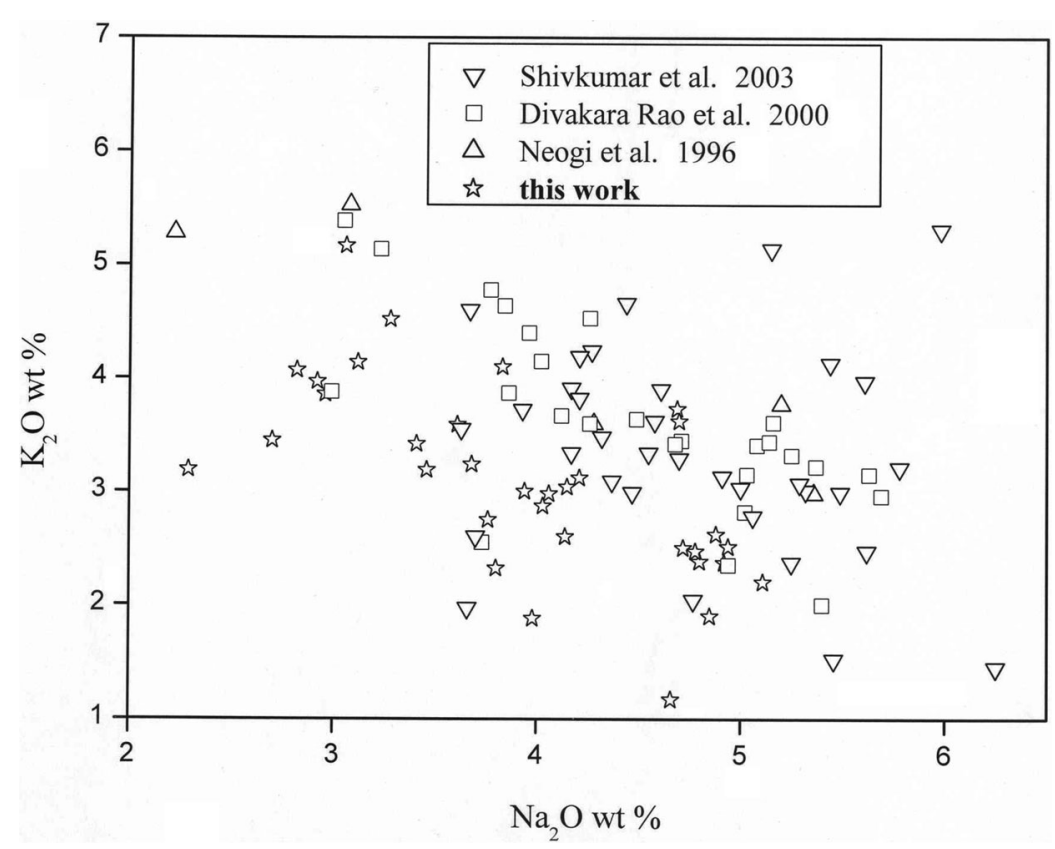

Figure 8. $\mathrm{Na}_{2} \mathrm{O}-\mathrm{K}_{2} \mathrm{O}$ plot for the Bijli Rhyolite samples. $\mathrm{Na}_{2} \mathrm{O}$ and $\mathrm{K}_{2} \mathrm{O}$ show mutually negative relationship.

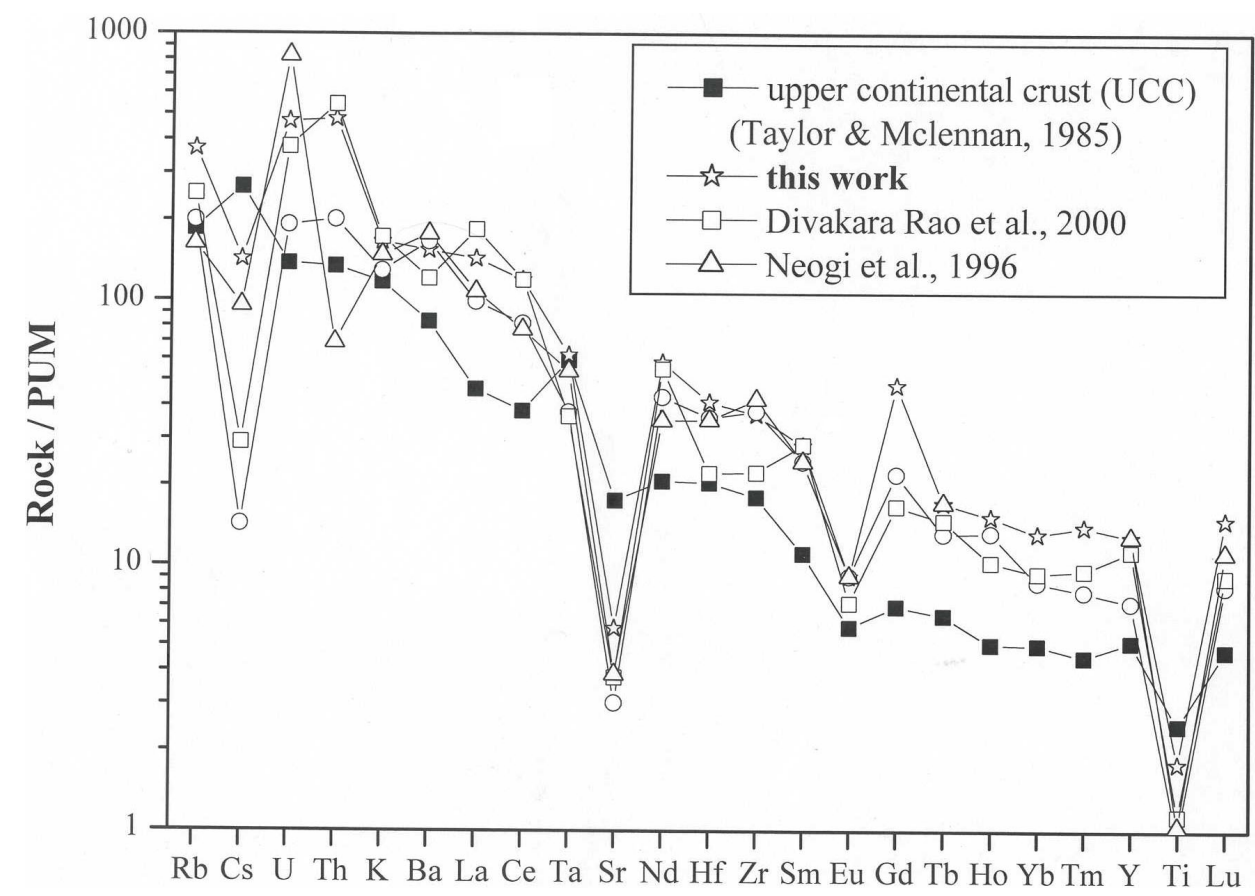

Figure 9. Primitive upper mantle (PUM)-normalized incompatible elements plot of the Bijli Rhyolite. PUM-normalized incompatible element concentrations of upper continental crust (UCC) are shown for comparison. PUM values are taken from McDonough and Sun (1995). Symbols are described in the legend.

clase, intersect the bulk compositional trend. From the proportion of intercepts of the join with the bulk compositional trend, plagioclase appears to be the main fractionating phase. On the other hand, in $\mathrm{Al}_{2} \mathrm{O}_{3}-\mathrm{Na}_{2} \mathrm{O}$ and $\mathrm{SiO}_{2}-\mathrm{CaO}$ diagrams, plagioclase and K-feldspar not only plot on the bulk compo- sitional trend, but their plots coincide with some bulk compositions (figure 12). This may be suggestive of feldspar-melt relationship, but does not argue for fractionation crystallization of feldspars, as removal of feldspars would drive the bulk composition away from it. Further arguments against K- 

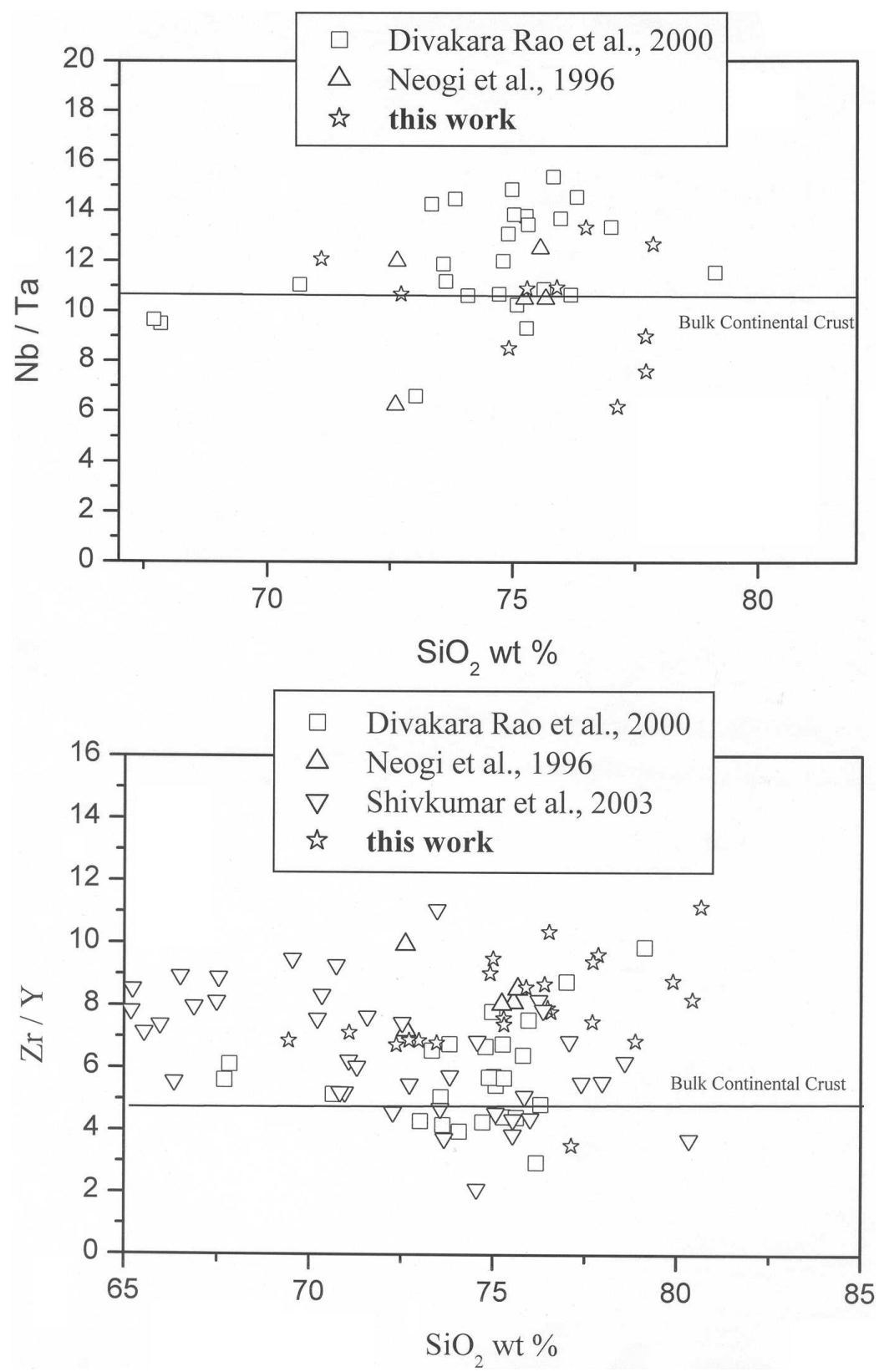

Figure 10. $\mathrm{Nb} / \mathrm{Ta}$ for the Bijli Rhyolite show near crustal values, but $\mathrm{Zr} / \mathrm{Y}$ are little higher than the bulk continental crust (BCC). Different symbols for different data sources, as shown in the legend.

feldspar fractional crystallization come from trace elements data. As already discussed, K-feldspar is the principal phenocrystic phase in our rocks, and its removal by fractionation would have considerably decreased $\mathrm{K}_{2} \mathrm{O}$, Ba and $\mathrm{Rb}$ concentrations and consequently decrease $\mathrm{Rb} / \mathrm{Sr}$ ratios with increasing silica. But the near constant $\mathrm{K}_{2} \mathrm{O}$ contents (4$5 \mathrm{wt} \%$ ) with little variation in Ba contents and no mutual negative relationship between $\mathrm{Rb} / \mathrm{Sr}$ and $\mathrm{SiO}_{2} \mathrm{wt} \%$ (tables 3 and 4, figure 4) do not suggest K-feldspar fractionation. K-feldspar rather occurs as a near-liquidus phase early in the crystallization history as also observed in many 'A-type gran- ite' (Landenberger and Collins 1996). Also, if negative Sr- and Eu- anomalies (figures 9 and 11) were indicative of plagioclase fractionation as argued by Divakara Rao et al (2000), Rb/Sr ratio would have significantly increased with increasing silica, which is also not observed in our samples (figure 4). Simultaneous rise in $\mathrm{Al}_{2} \mathrm{O}_{3}$ and $\mathrm{CaO}$ concentrations in the melt at a particular silica level $\left(\mathrm{SiO}_{2} \sim 76 \mathrm{wt} \%\right)$ (figure 7 ) rather indicate addition of plagioclase. Negative Sr- and Eu-anomalies thus could be indicative of retention of plagioclase in the residue during partial melting, as discussed below. 


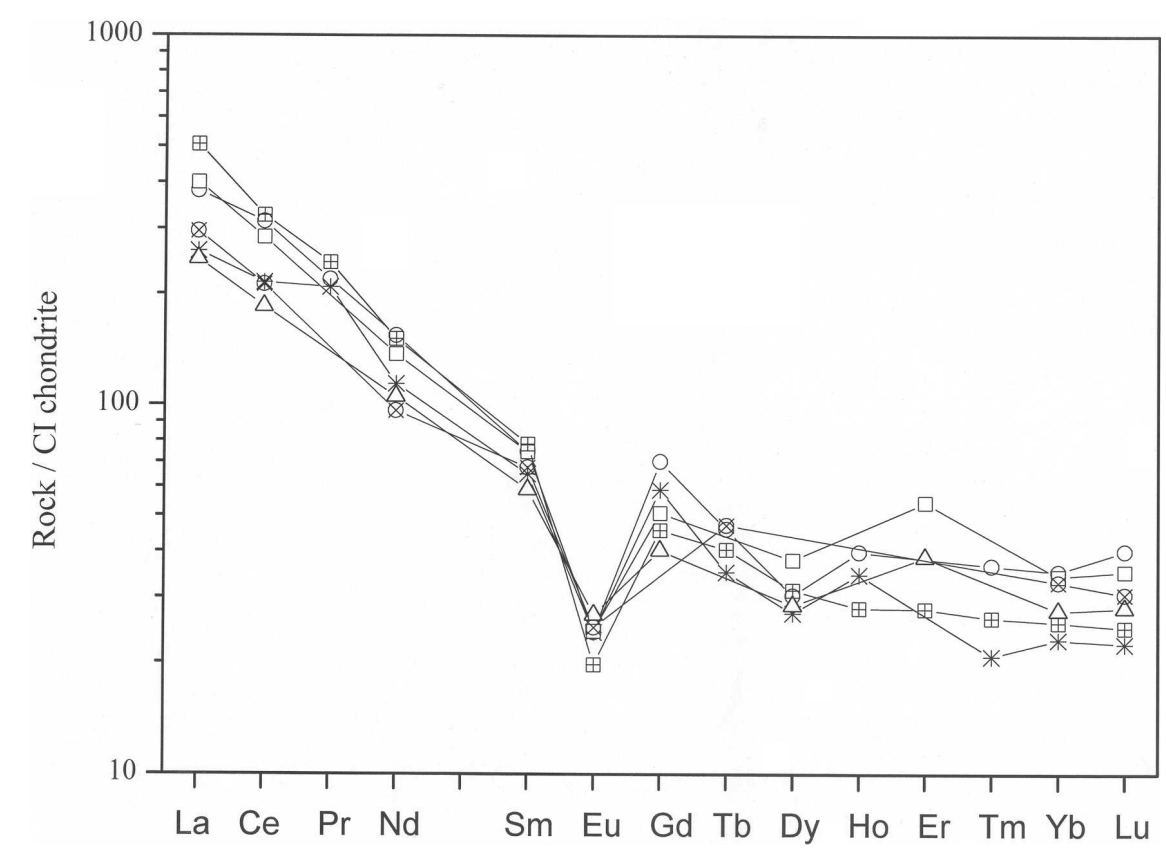

Figure 11. C1-chondrite normalized Rare Earth Elements (REE) plot for the Bijli Rhyolite samples.

\section{Accessory minerals}

Most felsic magmas are saturated with accessory minerals (REE-, Y-, Th-, U-bearing), which play an important role in controlling the geochemistry of the crustal melts (Watson 1988). Magmatic epidote has high to moderate REE contents. Fractionation of epidote may account for part of the strong negative Eu-anomalies in our samples. Allanite contains $\mathrm{Th}\left(\mathrm{ThO}_{2} \sim 1 \mathrm{wt} \%\right)$, but hardly any $\mathrm{U}\left(\mathrm{UO}_{2} \sim 0.0-0.2 \mathrm{wt} \%\right)$ (Bea 1996). High concentrations of Th and $\mathrm{U}$ in our samples thus possibly preclude any role for allanite. Low $\mathrm{Th} / \mathrm{U}$ ratios particularly in Kotri samples (e.g., Shivkumar et al 2003) may suggest fractionation of phases like Thorthosilicate. The concentrations of $\mathrm{Th}$ and $\mathrm{U}$ are highly variable in zircon, even among grains from the same thin section (Bea 1996). So low $\mathrm{Th} / \mathrm{U}$ values may also suggest zircon fractionation. The scattering in $\mathrm{Zr} / \mathrm{Y}$ ratios may also indicate zircon fractionation. Near crustal $\mathrm{Nb} / \mathrm{Ta}$ ratios in the rocks (figure 10) do not indicate fractionation of phases like niobotantalates. The role of LREE-rich accessory minerals such as monazite is not clear given the smooth LREE patterns in the samples (figure 11). Strong negative $\mathrm{Ti}$ anomalies may, however, indicate titano-magnetite fractionation, rather than sphene, because sphene fractionation would have resulted in $\mathrm{Y}$ depletion, which is not observed in the samples (figure 9). In summary, fractionation crystallization of feldspars and accessory phases were not important in the evolution of the Bijli melts, except for zircon and Thorthosilicate.

\section{2b Nature of source rock}

There is a lot of controversy about the possible nature of the crustal protolith for the generation of high silica rhyolite. Here, we evaluate the possibility of two types of crustal sources: (a) the possible basement granitoid gneissic rocks (Amgaon Gneiss) in the area, and (b) a deeper crustal source compositionally similar to the Average Archaean Granulite (AAG) of Rudnick and Presper (1990). Sarkar et al (1994), on the basis of mass balance computations, have suggested extensive partial fusion (60-68\%) of the granitoid basement for the generation of the Bijli rhyolites. Sedimentary rocks and its metamorphic equivalents are not suitable as source, because experimental studies reveal that the granitic melts produced by partial melting of this type of source are strongly peraluminous (Johanees and Holtz 1996; Patiño Douce 1999), whereas the Bijli rhyolites are dominantly metaluminous in composition.

\section{2c Comparison with experimental melts}

The normative compositions of the first melts produced by dry partial melting of charnockite at higher temperatures and pressure $\left(\sim 950^{\circ} \mathrm{C}\right.$, $15 \mathrm{kbar}$ ) (Litvinovsky et al 2000), and $\mathrm{H}_{2} \mathrm{O}$ undersaturated basaltic andesite to dacite melting at $\sim 1000^{\circ} \mathrm{C}$ at 1 atmosphere (Brugger et al 2003) are compared with the Bijli melts on a QAb-Or space (figure 13). The plots of the Bijli rhyolites apparently show scatter. Nevertheless, the plot brings out some useful information. 

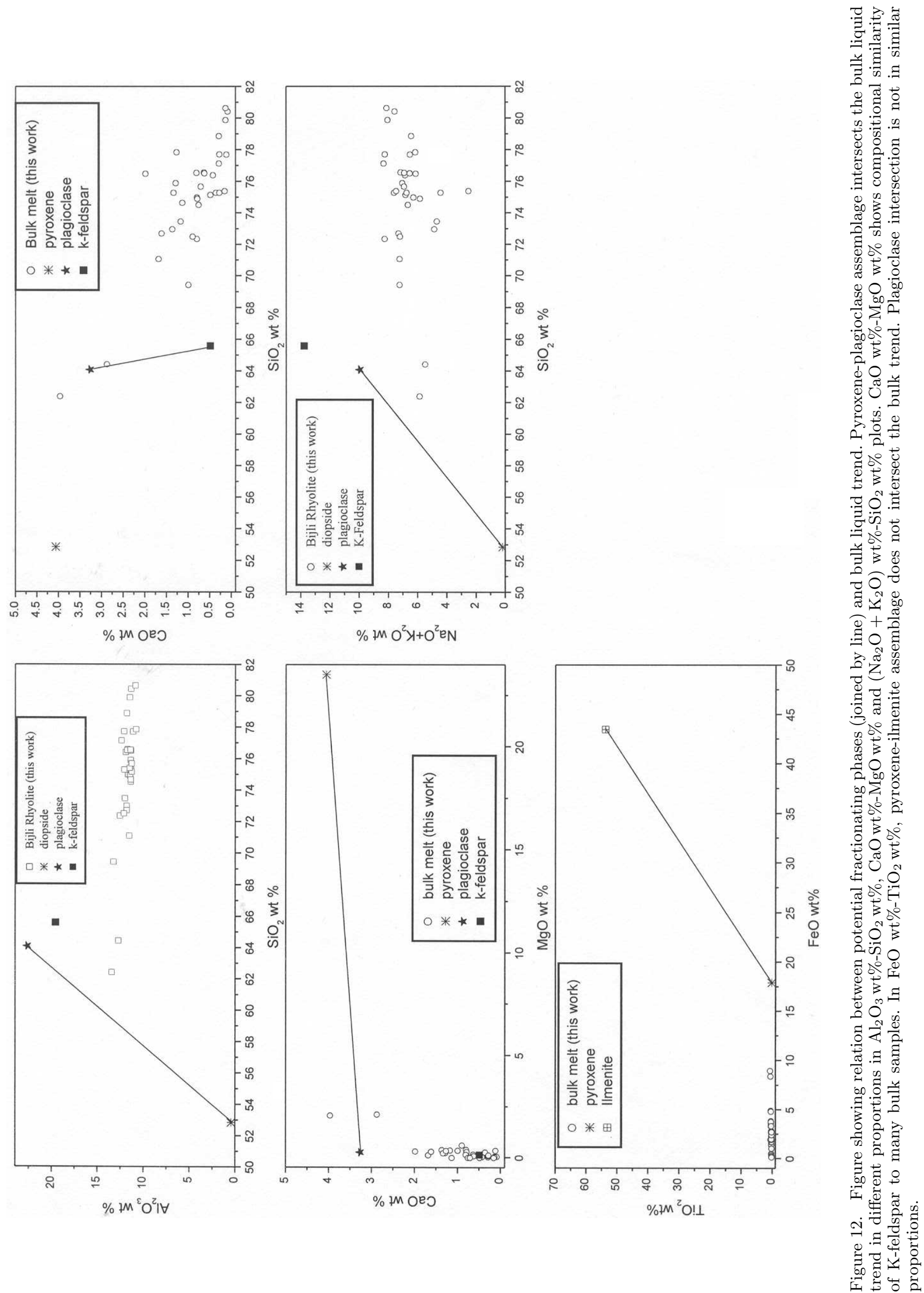

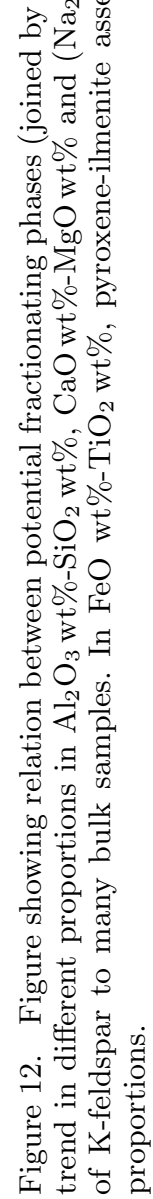




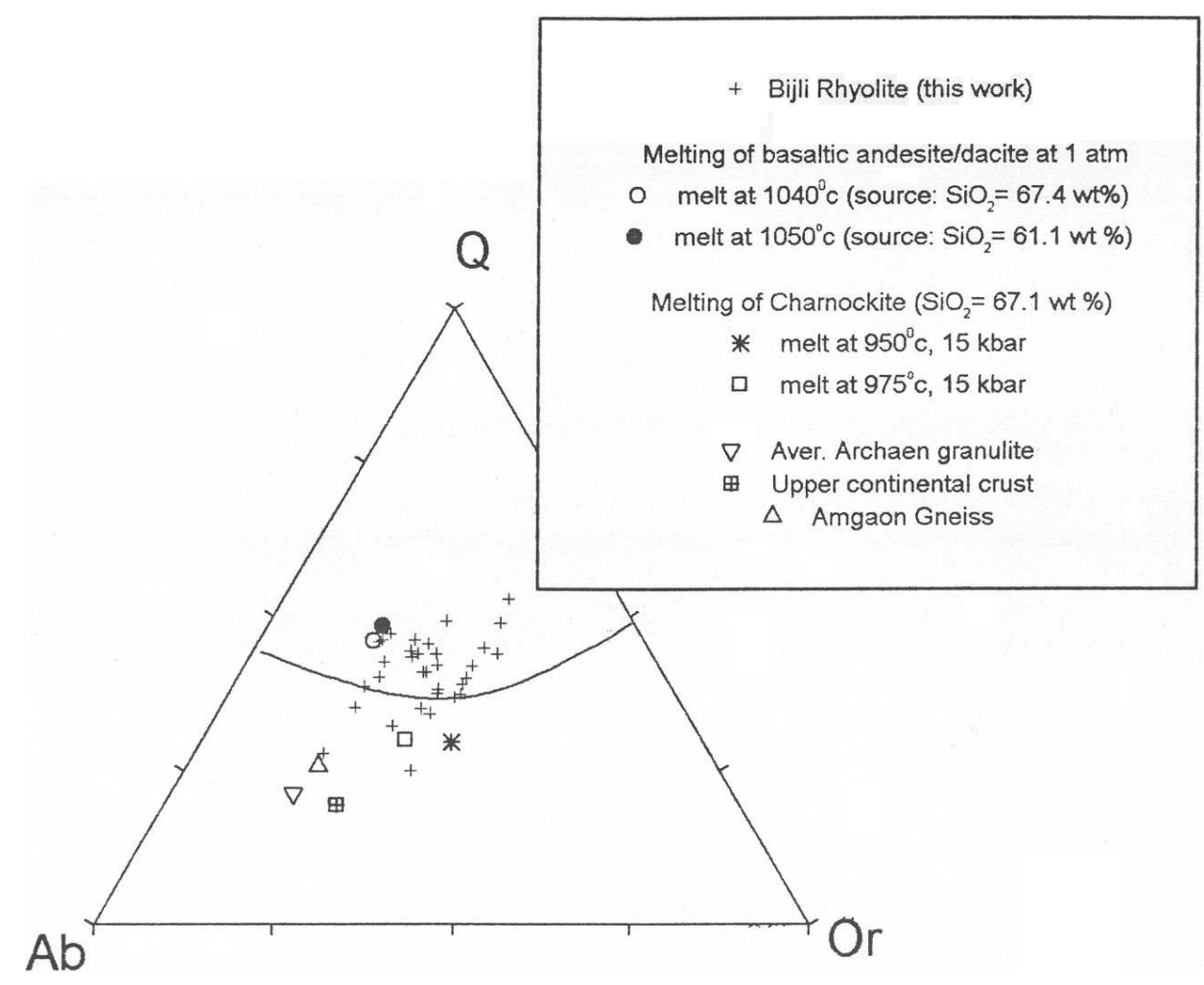

Figure 13. Plot of Bijli Rhyolite bulk compositions, experimental melts and crustal lithologies including the minimum in the Quartz (Q)-Albite (Ab)-Orthoclase (Or) system at $\mathrm{P}_{\mathrm{H} 2 \mathrm{O}}=1 \mathrm{kbar}$. Data sources: upper continental crust (UCC) (Taylor and McLennan 1985), average Archaean Granulite (AAG) (Rudnick and Presper 1990), Amgaon Gneiss (average) (Sarkar et al 1994), partial charnockite melts (Litvinovsky et al 2000), and partial basaltic andesite/dacite melts (Brugger et al 2003).

(a) There are samples which are compositionally not far from the normative composition of the first partial melt $\left(\begin{array}{llll}\mathrm{Ab}_{35.32} & \mathrm{Or}_{35.03} & \mathrm{Q}_{29.65} & \text { with }\end{array}\right.$ $\mathrm{SiO}_{2} \sim 72 \mathrm{wt} \%$ ) of charnockite melting.

(b) There is a continuous change in bulk rock compositions from partial melts of chanockite at high pressure $(15 \mathrm{kbar})$ to eutectic melt composition $\left(\mathrm{Ab}_{38.06} \mathrm{Or}_{15.98} \mathrm{Q}_{45.97}\right)$ of basaltic andesite/dacite melting (Brugger et al 2003) with concomitant rise in $\mathrm{Ab}$ and $\mathrm{Qtz}$ components.

(c) There are melts with similar levels of normative quartz as in (b), but elevated normative orthoclase at the expense of albite $\left(\begin{array}{llll}\mathrm{Ab}_{30.21} & \mathrm{Or}_{32.43} & \mathrm{Q}_{37.36}-\mathrm{Ab}_{23.24} & \mathrm{Or}_{32.02}\end{array}\right.$ $\left.\mathrm{Q}_{44.74}\right)$.

The Bijli samples compositionally similar to the type (a) might indicate that some deeper crustal source of charnockitic composition might be directly involved in the formation of silicic melts in the area. The bulk Amgaon granitoid composition (Sarkar et al 1994) is not much different from that of the bulk charnockite composition of Litvinovsky et al (2000), except for higher $\mathrm{Al}_{2} \mathrm{O}_{3}$ (17wt\%) and slightly lower $\mathrm{CaO}$ and $\mathrm{MgO}$ con- tents. The Amgaon rocks could thus be an equally potential source as suggested by Sarkar et al (1994). Irrespective of the crustal source, however, moderate negative $\mathrm{K}$ - and Eu-, and strong negative Sr-anomalies in the incompatible elements plot (figure 9) indicate the presence of both K-feldspar and plagioclase in the residue, which may have retained the elements resulting in negative anomalies and also much of $\mathrm{Al}_{2} \mathrm{O}_{3}$.

The increase in $\mathrm{Ab}$ and Qtz in our melts with a drop in pressure is consistent with experimental findings at decreasing crustal pressure (Patioño Douce and Beard 1995; Johannes and Holtz 1996). The change in melt compositions (type b) from 15 kbar pressure (crustal depth) to one atmosphere within a small temperature range of about $100^{\circ} \mathrm{C}$ (figure 13) can be attributed to a rapid drop in pressure leading to melt equilibration with surface conditions. This leads to suggest that the high temperature Bijli melts may have erupted soon after their generation that inhibited fractionation, consistent with our findings in section 7.2a. The high magmatic temperatures, in turn, lead to the enrichment in HFSE, characteristic of A-type granitic melts including the Bijli Rhyolite, owing to increased solubility of accessory 
phases (cf., Collins et al 1982). Low $\mathrm{H}_{2} \mathrm{O}$ activity $\left(\mathrm{a}_{\mathrm{H}_{2} \mathrm{O}}\right)$ with decreasing pressure at shallow crustal melting $(P \leq 4 \mathrm{kbar})$ causing the melt to be enriched in normative orthoclase at the expense of albite (type c) (Conrad et al 1988, Holtz and Johannes 1991) is also consistent with the melting regime considered here. So, there could as well be some contributions of shallower crustal components including the Amgaon Gneiss, if it is the basement to the Bijli Rhyolite (Sarkar 1957-58; Sarkar et al 1994). $\mathrm{H}_{2} \mathrm{O}$-undersaturated conditions, however, commonly prevail during partial melting in the middle and lower crust, and basalt-induced crustal melting is conducive to rapid generation of melts (Huppert and Sparks 1988; Annen and Sparks 2002).

\section{2d Trace element modeling}

An attempt has been made to further constrain the nature of the sources by selected trace element modeling. Models of different extent of melting of two different crustal sources are considered here. Major element data for the Amgaon granitoid rocks are not far from that of the upper continental crust (UCC) of Taylor and McLennan (1985). Since the trace element data for the Amgaon rocks are not available, and the upper continental crust (UCC) of Taylor and McLennan (1985) is believed to be compositionally similar to the Precambrian basement granitoids, the UCC is taken as a potential crustal source, as a first approximation, for modeling.

Melt segregation is a complex process to model in detail (Spiegelman and Kenyon 1992). The silicic melts have a higher permeability threshold, and thus probably behave according to the batch melting equation (Shaw 1970) as follows:

$$
C_{L} / C_{0}=1 / F+D-F D
$$

where $F=$ fraction of partial melting, $D=$ bulk distribution coefficient, $C_{0}=$ concentration of element in original source, $C_{L}=$ concentration of element in final melt

The normative minerals of the respective source compositions are considered as participating phases for the distribution of trace elements into the melt fraction. It is always a problem to choose the correct mineral/melt partition coefficients for individual elements in different phases. Besides, comparative data of partition coefficients in silicic systems are scarce, and partition coefficients for minerals from high-silica rhyolites differ substantially from those of less silicic magmas. Nevertheless, partition coefficient data for individual elements in highly silicic melts (e.g., Mahood
Table 6. Partition co-efficient data used for calculations.

\begin{tabular}{clcccccc}
\hline & qtz & k-feld & plag & cpx & opx & ilm & Apt \\
\hline $\mathrm{K}$ & 0.013 & 0.00 & 0.263 & 0.037 & 0.002 & 0.00 & 0.00 \\
$\mathrm{Sc}$ & 0.01 & 0.02 & 0.06 & 50 & 18 & 5.90 & 0.00 \\
$\mathrm{Ti}$ & 0.04 & 0.00 & 0.00 & 0.00 & 0.00 & 0.00 & 0.10 \\
$\mathrm{Sr}$ & 0.00 & 7.30 & 13 & 0.516 & 0.009 & 0.00 & 0.00 \\
$\mathrm{Rb}$ & 0.015 & 1.80 & 0.06 & 0.032 & 0.003 & 0.00 & 0.00 \\
$\mathrm{Th}$ & 0.01 & 0.02 & 0.05 & 0.13 & 0.15 & 7.50 & 0.00 \\
$\mathrm{La}$ & 0.012 & 0.07 & 0.34 & 0.87 & 0.84 & 7.10 & 14.5 \\
$\mathrm{Ce}$ & 0.017 & 0.02 & 0.24 & 1.40 & 0.99 & 7.80 & 21.1 \\
$\mathrm{Sm}$ & 0.017 & 0.02 & 0.15 & 3.80 & 1.70 & 6.90 & 46 \\
$\mathrm{Nd}$ & 0.024 & 0.04 & 0.19 & 2.40 & 1.30 & 7.60 & 32.8 \\
$\mathrm{Eu}$ & 0.073 & 6.50 & 7.90 & 3.30 & 0.81 & 2.50 & 26 \\
$\mathrm{Yb}$ & 0.025 & 0.03 & 0.10 & 4.0 & 2.4 & 4.1 & 15.4 \\
$\mathrm{Lu}$ & 0.024 & 0.04 & 0.13 & 3.80 & 2.40 & 3.60 & 13.8 \\
$\mathrm{Ba}$ & 0.06 & 24 & 3.3 & 0.131 & 0.003 & 0.00 & 0.00 \\
$\mathrm{Ta}$ & 0.008 & 0.01 & 0.03 & 0.13 & 0.20 & 106 & 0.00 \\
$\mathrm{U}$ & 0.04 & 0.04 & 0.13 & 0.00 & 0.17 & 3.20 & 0.00 \\
$\mathrm{Hf}$ & 0.057 & 0.04 & 0.29 & 0.56 & 0.22 & 3.10 & 0.10 \\
$\mathrm{Cr}$ & 0.00 & 0.00 & 0.00 & 0.00 & 0.00 & 3.00 & 0.00 \\
& & & & & & &
\end{tabular}

$\mathrm{qtz}=$ quartz, $\mathrm{k}$-felds $=\mathrm{k}$-feldspar, plag $=$ plagioclase, $\mathrm{cpx}=$ clino-pyroxene, opx $=$ ortho-pyroxene, ilm $=$ ilmenite, Apt = apatite.

Data taken from Mahood and Hildreth (1983), Nash and Crecraft (1985). Rb, Sr, K, Ba for cpx and opx from Arth (1976).

and Hildreth 1983; Nash and Crecraft 1985) are used to calculate the bulk distribution coefficient for each element for the Bijli melts. The partition coefficient data of Nash and Crecraft (1985) have some advantages over those of Mahood and Hildreth (1983), for no partition data are available in the latter for plagioclase, clino- and orthopyroxenes separately for the same eruptive unit. REE partition coefficients of Nash and Crecraft (1985) are, however, very similar to that reported by Mahood and Hildreth (1983) and Arth (1976). With these limitations, the same set of partition coefficient values (table 6) are used for all the calculations irrespective of the sources considered here.

Since the modal abundance of REE, Th, U, Y-bearing accessory minerals like Zircon, monazite, Th-orthosilicate in AAG and UCC are not known, these could not be taken as participating phases. Moreover, consideration of these phases would have complicated the situation as they do not generally obey Henry's law during melt-solid partitioning, their concentrations in partial melts not being ruled by crystal-melt distribution coefficients but by solubility relations and reaction kinetics (Rapp and Watson 1986). 


\section{$7.2 \mathrm{e}$ Results}

Geochemical mass balance (table 7) shows that trace element data fits better with $25-35 \%$ partial melting of AAG rather than a source of UCC composition of Taylor and McLennan (1985), particularly in terms of $\mathrm{Sr}, \mathrm{Rb}, \mathrm{Th}, \mathrm{La}, \mathrm{Nd}, \mathrm{Lu}, \mathrm{Sc}$ and $\mathrm{Hf}$. For some incompatible elements, e.g., Ba, K, Ti, $\mathrm{Ta}, \mathrm{U}, \mathrm{Sm}, \mathrm{Yb}$, however, the extent of melting are more uncertain, which could partly be attributed to compositional heterogeneity of crustal protolith including the depth of melting in the crust.

Given these uncertainties, partial melting ( $\sim 30 \%)$ of deeper crustal rocks similar to the AAG may better explain the data. The occurrence of charnockite patches, lenticular bodies and enclaves within the granitic rocks of the Archaean complex in south and north Bastar (Bhate and Krishna Rao 1981) also supports the model. Similar Ta/Th ratios of the Bijli Rhyolite (0.060) and of average granulite (0.065), but higher values for UCC (0.13) (Sensarma et al 2002) also points to a deeper crustal source. However, limited role of the UCC including the Amgaon Gneiss cannot be ruled out, as some trace elements fit quite well with those of UCC values (table 7).

LILE depletion, particularly depletion of U compared to Th has been generally assumed to be a common feature of granulites (Rudnick et al 1985). We do not consistently find $U$ depletion in our rocks. So, the deeper crustal source in Dongargarh was probably melt-undepleted in character. Meltundepleted character of granulites, though not very common, is also reported from the southern Indian granulites (Weaver 1980; Janardhan et al 1983).

\section{Crust-mantle interaction}

It is in this scenario that the question of whether the komatiitic basalts provided only heat for crustal melting, or also interacted chemically with it, needs to be addressed. This assumes significance as recent experimental studies confirm reaction of basaltic magmas with quartzofeldspathic rocks yielding silicic magmas (Patiño Douce 1999 and references therein).

\subsection{Constraints from major elements}

Interaction of mantle-derived melts and crustal rocks in terms of major elements should involve alkali elements, $\mathrm{Al}_{2} \mathrm{O}_{3}, \mathrm{CaO}, \mathrm{FeO}, \mathrm{MgO}$ and $\mathrm{TiO}_{2}$ (Patiño Douce 1999). We plot the major element compositions of crustal melts produced by experimental dehydration melting of biotite gneiss and quartz-amphibolites at 3-15 kbar (Patiño Douce and Beard 1995), and the Bijli rocks as a ratio between two variables versus the sum of the variables. The Bijli melts yield a tight trend that passes close to, but not exactly within the fields of crustal melts (figure 14). It is interesting that the basaltic komatiite/high-Mg basalt samples reported from the Dongargarh belt (Sensarma 2001) plot at one end of this trend. The Bijli rocks have two distinct sub-trends:

- constant $\left(\mathrm{Na}_{2} \mathrm{O}+\mathrm{K}_{2} \mathrm{O}\right) /\left(\mathrm{FeO}+\mathrm{MgO}+\mathrm{TiO}_{2}\right)$ and $\mathrm{Al}_{2} \mathrm{O}_{3} /\left(\mathrm{FeO}+\mathrm{MgO}+\mathrm{TiO}_{2}\right)$, but wide range in $\mathrm{Na}_{2} \mathrm{O}+\mathrm{K}_{2} \mathrm{O}+\mathrm{FeO}+\mathrm{MgO}+\mathrm{TiO}_{2}$ and $\mathrm{Al}_{2} \mathrm{O}_{3}+$ $\mathrm{FeO}+\mathrm{MgO}+\mathrm{TiO}_{2}$, and

- wide range in $\left(\mathrm{Na}_{2} \mathrm{O}+\mathrm{K}_{2} \mathrm{O}\right) /\left(\mathrm{FeO}+\mathrm{MgO}+\mathrm{TiO}_{2}\right)$ and $\mathrm{Al}_{2} \mathrm{O}_{3} /\left(\mathrm{FeO}+\mathrm{MgO}+\mathrm{TiO}_{2}\right)$, but constant $\mathrm{Na}_{2} \mathrm{O}+\mathrm{K}_{2} \mathrm{O}+\mathrm{FeO}+\mathrm{MgO}+\mathrm{TiO}_{2}$ and $\mathrm{Al}_{2} \mathrm{O}_{3}+$ $\mathrm{FeO}+\mathrm{MgO}+\mathrm{TiO}_{2}$.

The Bijli samples with constant $\left(\mathrm{Na}_{2} \mathrm{O}+\right.$ $\left.\mathrm{K}_{2} \mathrm{O}\right) /\left(\mathrm{FeO}+\mathrm{MgO}+\mathrm{TiO}_{2}\right)$ and $\mathrm{Al}_{2} \mathrm{O}_{3} /(\mathrm{FeO}+$ $\mathrm{MgO}+\mathrm{TiO}_{2}$ ) have similar values to that of the basaltic komatiites, but slightly lower $\mathrm{Al}_{2} \mathrm{O}_{3} /\left(\mathrm{FeO}+\mathrm{MgO}+\mathrm{TiO}_{2}\right)$ compared to the amphibolite considered here (figure 14). Wide range in $\mathrm{Na}_{2} \mathrm{O}+\mathrm{K}_{2} \mathrm{O}+\mathrm{FeO}+\mathrm{MgO}+\mathrm{TiO}_{2}$ and $\mathrm{Al}_{2} \mathrm{O}_{3}+\mathrm{FeO}+\mathrm{MgO}+\mathrm{TiO}_{2}$ in the same set of samples can be attributed to variable contributions of crust and mantle-derived basaltic komatiite melts into the Bijli liquid with mantle contribution largely in terms of $\mathrm{Fe}, \mathrm{Mg}$ and $\mathrm{Ti}$. Both AAG and the Amgaon Gneiss plot very close to these samples implying their involvement. The second type of samples, on the other hand, calls for predominant participation of shallow crustal components $(\leq 4 \mathrm{kbar})$ comparatively richer in $\mathrm{Na}_{2} \mathrm{O}, \mathrm{K}_{2} \mathrm{O}$, $\mathrm{Al}_{2} \mathrm{O}_{3}$, with limited mantle input. We are not certain about the identity of this crustal component in Dongargarh, but low $\mathrm{Ca}, \mathrm{CaO}+\mathrm{Al}_{2} \mathrm{O}_{3}(\sim 12)$ and $\mathrm{CaO} / \mathrm{Al}_{2} \mathrm{O}_{3}$ (0.02) of the rocks do not argue for the Amgaon Gneiss, which has higher $\mathrm{CaO}$ and $\mathrm{Al}_{2} \mathrm{O}_{3}$ contents and $\mathrm{CaO} / \mathrm{Al}_{2} \mathrm{O}_{3}$ ratios. The compositions of these samples are rather analogous to the experimental partial melt compositions with a calc-alkaline granite protolith at $4 \mathrm{kbar}$ pressure (Patino Douce 1997). So, variable extents of interaction between mantle-derived basaltic komatiite melts and shallow to deeper crustal components, not only shallow hybridization of basalts and calcalkaline rocks as suggested for the origin of the rhyolites in some basaltic plateaus (Paraná and Karoo) (Patiño Douce 1999), may have given rise to the hybrid Bijli melts.

\subsection{Further constraints from oxygen isotope}

Igneous rocks with $\mathrm{O}$-isotope values in the range of +5 to $+8 \%$, as observed in our samples (table 5 ), are generally considered to have been derived from 


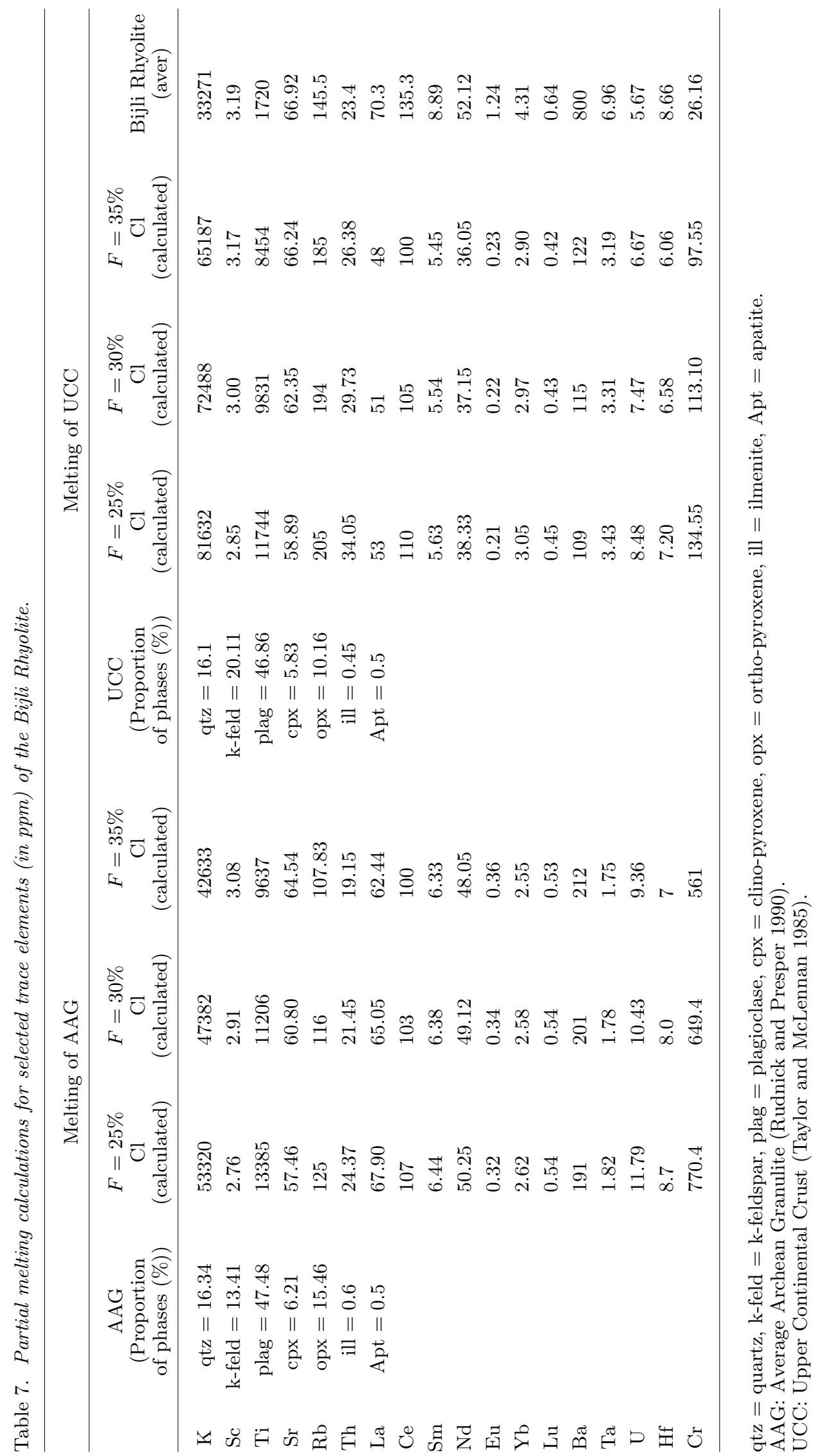



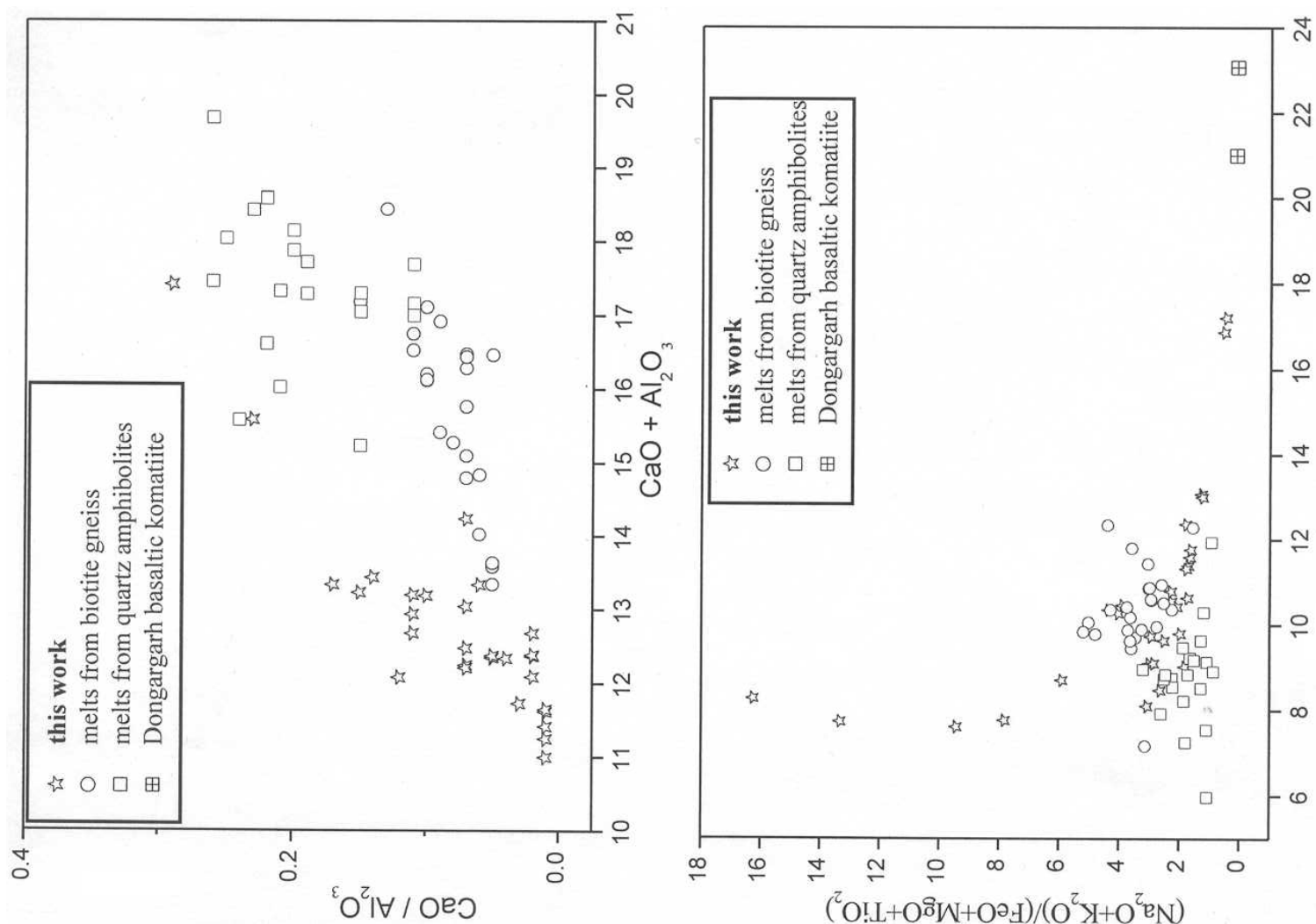

สำ

ิิ)

\&

๘

荧

矛 :

品

:

일

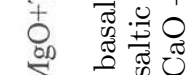

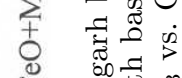

年

员券造

范

สี

용. 물

$\rightarrow$ 角

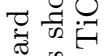

范

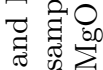

$8: \because+$

品。

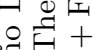
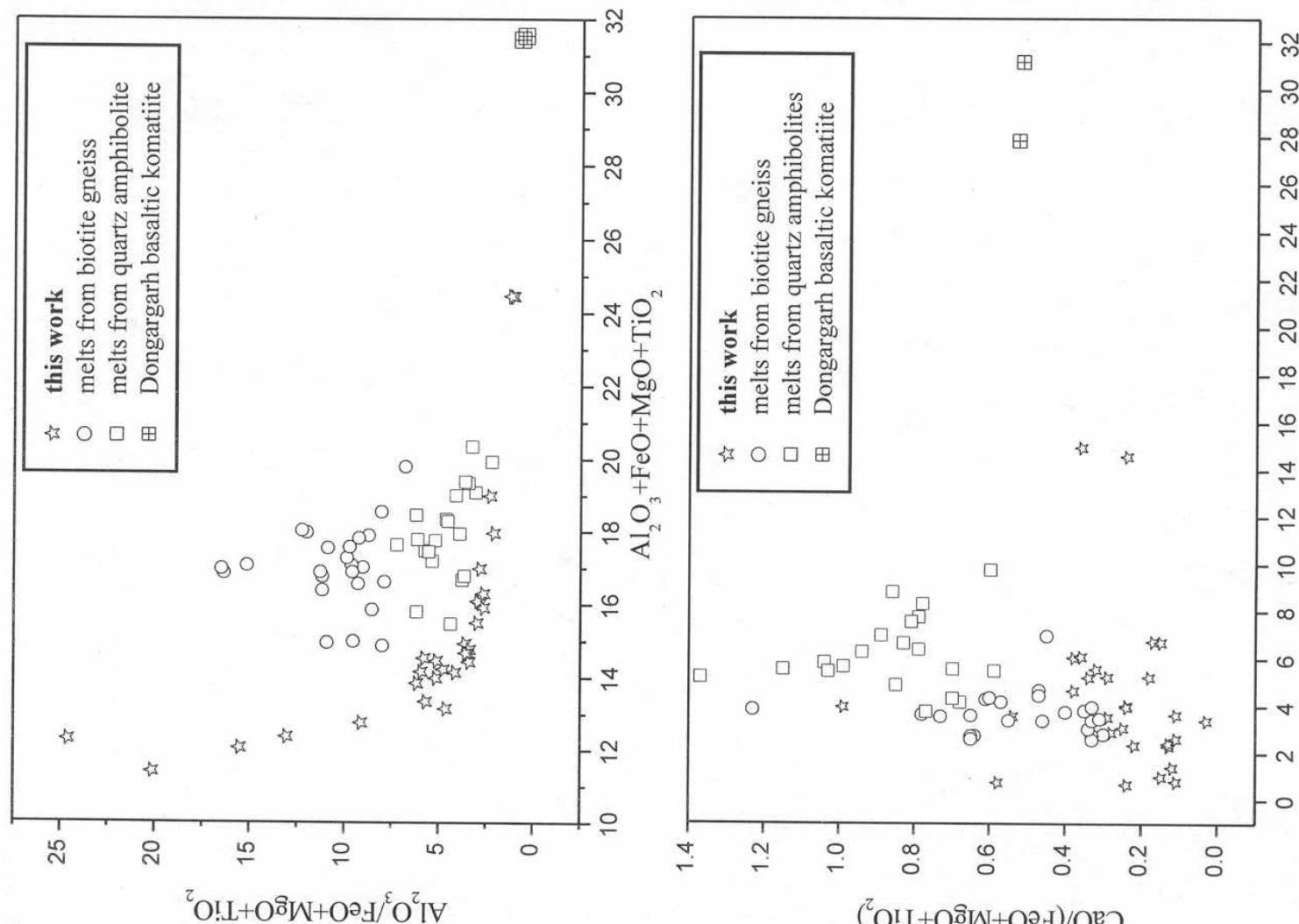

تृ:

os

ํ.

ब范

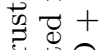

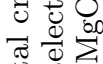

要要

$\mathrm{O}^{N}$ व्च

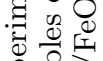

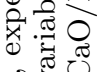

in

¿

$\because$ 讪:

ต

of की

tᄒ

귱 की

당

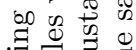

मे

का

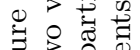

500

I 팡 잉

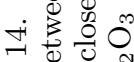

o 8 क

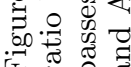


a source including mafic to intermediate lower crust (granulites) $(8 \% \circ \pm 1.8 \%$ o $)$ and mantle derived materials, but not upper crustal rocks with higher $\delta^{18} \mathrm{O}$ value (>13\%) (Kempton and Harmon 1992). Average $\mathrm{K} / \mathrm{Rb}$ (300) in our rocks (figure 4) may reflect the presence of some mafic component, as average compositions of common igneous rocks must include rocks of basaltic composition (cf., Rudnick and Presper 1990). Our oxygen isotope data is therefore evaluated in terms of interaction of granulitic crust and mantle-derived melt. Since oxygen constitutes approximately half the mass of the rock, crust-mantle interaction in terms of oxygen isotope should approximate simple mixing process. For example, addition of about $15 \%$ of mantlederived material $\left(\delta^{18} \mathrm{O}_{\text {mantle }}=+5.7 \%\right.$ ) to a lower crust $\left(\delta^{18} \mathrm{O}_{\text {lowercrust }}=+8 \%\right.$ o $)$ may give rise to a melt with $\delta^{18} \mathrm{O}$ of about $7.65 \%$, similar to DM21 value. On the other hand, only $10 \%$ crustal contribution would be required to achieve a value of $6.1 \%$, similar to DM7. So, variable contribution of deeper crust and mantle could thus be responsible for the spread in $\delta^{18} \mathrm{O}$ values in our samples. On the other hand, a range in $\delta^{18} \mathrm{O}$ values from 4.4 to $7.6 \%$, and low initial ${ }^{87} \mathrm{Sr} /{ }^{86} \mathrm{Sr}$ ratios of 0.7031 and 0.7057 in the samples may also be explained in terms of interaction of a mafic source rock and hydrothermal fluid. Some recent rhyolites from Iceland show such oxygen and $\mathrm{Sr}$ isotope signatures and have been explained by involvement of hydrothermally altered oceanic rocks. Irrespective of the possibilities, isotopic signatures in our samples well argue for contributions of mafic components in the origin of the Bijli Rhyolite.

The nature of these chemical interactions is complex, and may involve assimilation, magma mixing, crystal accumulation (Hildreth and Moorbath 1988). It is not the purpose of this paper to elucidate the details, nor the relative importance of all these processes. Nevertheless, the present contribution highlights that crust-mantle interaction was an important process, wherein komatiitic basalts did not only supply heat to partially melt the crust, but contributed material to generate the hybrid silicic liquid. So, basaltic magmas are involved in the origin of the Bijli Rhyolite both physically and chemically. The recent discovery of a Siliceous High Magnesian Basalt (SHMB), which indicates basaltic komatiite and Bijli Rhyolite interaction and is occurring in spatial proximity to the Bijli Rhyolite (Sensarma et al 2002), strongly supports the role of crust-mantle interaction in the origin of the Bijli melts. Similar suggestion is also made for producing the Karoo rhyolites (Cox 1988) and the large-volume silicic volcanic centers in the western USA (Johnson 1991). It may happen that fluid introduction partly occurred as a consequence of brittle fracturing of the crust during the period between basaltic komatiite underplating and melting to produce the rhyolitic magmas.

\section{Regional implication}

Absence of hydrous phases and low $\mathrm{Al}_{2} \mathrm{O}_{3}$ content $(\sim 12 \mathrm{wt} \%)$, elevated HFSE, LILE and LREE contents in our rocks reflect its formation in an essentially anhydrous system (e.g., Collins et al 1982). An independent study by Bergantz (1989) also emphasized that liquid composition obtained under dry partial melting at $\sim 10 \mathrm{kbar}$ (crustal depth) more commonly matches the natural melt composition compared to that in saturated conditions. Low $\mathrm{aH}_{2} \mathrm{O}$ also requires higher temperature $\left(\sim 950^{\circ} \mathrm{C}\right)$ during partial melting (Clemens and Vielzeuf 1987; Johannes and Holtz 1996), which fits better for our samples (see above). Presence of anorthoclase in the rocks also indicates high temperature for the melts. This temperature was attainable in the given geologic situation in Dongargarh where successive high Mg basalts of mantle plume origin overlie the Bijli Rhyolite (Sensarma 2001), as discussed earlier.

The high silica rhyolites in the Dongargarh belt therefore manifest the onset of crustal growth at or near the end Archaean-Palaeoproterozoic in the central Indian Craton, where crustal mobilization at various depth as well as material input from deep mantle were responsible to build the new crust. The mantle-derived basaltic komatiite supplied heat and triggered melting at middle to lower crustal level, which subsequently involved shallower crust as well. The rapid eruption of the high temperature rhyolitic melts not only inhibited fractional crystalization, but is also indicative of a rapid drop in pressure related to decompression in an extensional setting within the crust. The Amgaon Gneiss may or may not be the basement on which the Bijli Rhyolite was laid down, but is not the only source component to the high silica rhyolite melts, as suggested by Sarkar et al (1994). Based on field and petrographic studies, we earlier suggested near contemporaneous relation between the Bijli Rhyolite and the immediately overlying Pitepani Volcanics in the area (Sensarma and Mukhopadhyay 2003). The common process of crust-mantle interaction in the origin of the Bijli Rhyolite as well as the SHMB-type lava in the Pitepani Volcanics (Sensarma et al 1999, 2002) surely indicates their contemporaneity, and need not be placed across an unconformity (Sarkar 1957; Sarkar et al 1994).

\section{Concluding remarks}

The following conclusions can be drawn from this study: 
- The Bijli Rhyolite is rhyolite to high silica rhyolite, and show close similarity to "A-type granite".

- It is neither a product of fractionation of a basaltic magma, nor is related to fractional crystallization of partial crustal melts. It is a product of crust-mantle interaction where crustal mobilization took place at various crustal depths. Deep crust compositionally similar to the average Archaean granulite of Rudnick and Presper (1990), shallower crust with high alkali, but low $\mathrm{CaO}, \mathrm{Al}_{2} \mathrm{O}_{3}$ contents, the Amgaon Gneiss and the basaltic komatiitic melts/high-Mg basaltic melts had variable contributions in the origin of the hybrid Bijli melts. About 30\% partial melting of average Archaean granulite compared to the Amgaon Gneiss better explain the data.

- The Amgaon granitoid gneiss of Sarkar et al (1994) may or may not be the basement to the Bijli Rhyolite in the area, but cannot be the sole source for the Bijli melt as advocated by Sarkar et al (1994).

\section{Acknowledgements}

A DAAD-fellowship to S S supported the major part of the work. Prof. Dr. Herbert Palme (Köln), Professor V Rajamani (JNU, New Delhi) and GSI, Calcutta for generous laboratory support to S.S, Prof. Dr. Sumit Chakraborty (Bochum) for discussions on several occasions, Dr. Markus Klein and Dr. Gerd Wreckwerth (Köln) for their invaluable support during EPMA and INAA work, Professor S K Sen for critical reading an earlier version of the manuscript and offering valuable suggestions. Critical reviews by Dr. A Patiño Douce (University of Georgia, USA) and Dr. J P Liégeois (Africa Museum, Belgium) are thankfully acknowledged.

\section{References}

Arndt N T 1994 Archean komatiite. In: Archean Crustal Evolution. (ed.) Condie K C (Amsterdam: Elsevier) $11-44$

Annen C and Sparks R S J 2002 Effects of repetitive emplacement basaltic intrusions on thermal evolution and melt generation in the crust; Earth Planet. Sci. Lett. 203 937-955

Arth J G 1976 Behaviour of trace elements during magmatic processes - a summary of theoretical models and their applications; J. Res. U.S. Geol. Surv. 4 41-47

Asprey L B 1976 The preparation of very pure fluorine gas; Journal of Flourine Chemistry 7 359-361

Ayalew D, Barbey P, Marty B, Reisberg L, Yirgu G and Pik R 2002 Source, genesis, and timing of giant ignimbrite deposits associated with Ethiopian continental flood basalts; Geochimica et Cosmochimica Acta 66 1429-1448
Bea F 1996 Residence of REE, Y, Th and U in Granites and Crustal Protoliths Implications for the chemistry of crustal melts; Journal of Petrology 37 521-552

Bellieni G, Comin-Chiaramonti P, Marques L S, Martinez L A, Melfi A J, Nardy A J R, Papatrechas C, Piccirillo E M, Roisenberg A and Stolfa D 1986 Petrogenetic aspects of acid and basaltic lavas from the Parana Plateau (Brazil): geological, mineralogical and petrochemical relationships; Journal of Petrology 27 915-944

Bergantz G W 1989 Underplating and Partial Melting: Implicaions for Melt Generation and Extraction; Science 245 1093-1095

Bhate V D, Krishna Rao S V G 1981 Charnockitic rocks of North Bastar, Madhya Pradesh; Geol. Surv. Ind. Spl. Publ. 3 109-113

Brugger C R, Johnston A D, Cashman K V 2003 Phase relations in silicic systems at one-atmosphere pressure; Contributions to Mineralogy and Petrology 146 356-369

Clayton R N and Mayeda T K 1963 The use of bromine pentafluoride in the extraction of oxygen from oxides and silicates for isotopic analyses; Geochimica et Cosmochimica Acta 27 43-52

Clemens J D and Vielzeuf D 1987 Constraints on melting and magma production in the crust; Earth and Planetary Science Letters 86 287-306

Coleman D S and Walker J D 1992 Evidence for the Generation of Juvenile Granitic Crust during continental extension, Mineral Mountains Batholith, Utah; Journal of Geophysical Research 97 11011-11024

Collins W J, Beams S D, White A J R and Chappell B W 1982 Nature and Origin of A-Type granites with particular reference to southeastern Australia; Contributions to Mineralogy and Petrology $80189-200$

Conrad W K, Nicholls I A, Wall V J 1988 Water-saturated and -undersaturated melting of metaluminous and peraluminous crustal compositions at $10 \mathrm{~kb}$ : evidence for the origin of silicic magmas in the Taupo Volcanic Zone, New Zealand, and other occurrences; Journal of Petrology 29 765-803

Cox K G 1988 The Karoo Province. In: Continental Flood Basalts, McDougal J D (ed.) Kluwer, 279-321

Cox K G, Bell J D and Pankhurst R J 1987 The Interpretation of Igneous Rocks; George Allen \& Unwin, London

Divakara Rao V, Narayana B L, Rama Rao P, Murthy N N, Subba Rao M V, Mallikharjuna J and Reddy G L N 2000 Precambrian Acid Volcanism in Central India Geochemistry and Origin; Gondwana Research 3 215226

Downes H 1993 The nature of the lower continental crust of Europe: Petrological and geochemical evidence from xenoliths; Physics of the Earth and Planetary Interiors 79 195-218

Eby G N 1990 The A-type granitoids: A review of their occurrence and chemical characteristics and speculations on their petrogenesis; Lithos 26 115-134

Gangopadhyay P K and Roy A 1997 Petrogenetic significance of Rhyolite-Granite suite of Dongargarh Supergroup, Central India; Indian Minerals $\mathbf{5 1} 123$ 136

Garland F, Hawkesworth C J and Mantovani S M 1995 Description and Petrogenesis of the Paraná Rzhyloites, Southern Brazil; Journal of Petrology 36 1193-1227

Giritharan T S and Rajamani V 1998 Geochemistry of the metavolcanics of the Hutti-Maski schist belt, South India: implications to gold metallogeny in the eastern Dharwar Craton; Journal of the Geological Society of India $\mathbf{5 1}$ 583-594 
Harrison T M and Watson E B 1984 The behaviour of apatitie during crustal anatexix: equilibrium and kinetic considerations; Geochimica et Cosmochimica Acta $\mathbf{4 8}$ 1468-1477

Hess P C 1989 Origin of igneous rocks. Harvard University Press, Cambridge, Massachusetts

Hildreth W 1981 Gradients in Silicic Magma Chambers: Implications for Lithospheric Magmatism; Journal of Geophysical Research 86 10153-10192

Hildreth W and Moorbath S 1988 Crustal contribution to arc magmatism in the Andes of Central Chile; Contributions to Mineralogy and Petrology 98 455-489

Hoffbauer R, Hoernes S and Fiorentini E 1994 Oxygen isotope thermometry on granulite grade rocks from Sri Lanka; Precambrian Research 66 199-220

Holtz F and Johannes W 1991 Genesis of peraluminous granites I. Experimental investigation of melt compositions at 3 and $5 \mathrm{~kb}$ and various $\mathrm{H}_{2} \mathrm{O}$ activities; Journal of Petrology 32 935-958

Huppert H E and Sparks R S J 1988 The generation of granitic magmas by intrusion of basalt into continental crust; Journal of Petrology 29 599-624

Janardhan A S, Newton R C and Hansen E C 1983 Transformation of Penninsular gneiss to charnockite in southern Karnataka. In: Precambrian of South India. Naqvi S M and Rogers J J W (eds.) Geological Society of India Memoir 4 417-435

Johannes W and Holtz F 1996 Petrogenesis and Experimental Petrology of Granitic Rocks. Springer 344p

Johnson C M 1991 Large scale crust formation and lithosphere modification beneath Middle to Late Cenozoic calderas and volcanic fields, western North America; Journal of Geophysical Research 96 13485-13507

Kempton P D and Harmon R S 1992 Oxygen isotope evidence for large-scale hybridization of the lower crust during magmatic underplating; Geochimica et Cosmochimica Acta 56 963-970

Krishnamurthy P, Sinha D K, Rai A K, Seth D K and Singh S N 1990 Magmatic rocks of the Dongargarh Supergroup, Central India - Their Petrological evolution and Implications on Mettallogeny; Geological Survey of India Special Publication 28 303-319

Landenberger B and Collins W J 1996 Derivation of A-type Granites from a dehydrated Charnockitic lower crust: evidence from the Chaelundi Complex, Eastern Australia; Journal of Petrology 37 145-170

Le Bas M J, Maitre Le, Streckeisen A and Zanettin B 1986 A chemical classification of volcanic rocks based on the total alkali-silica diagram; Journal of Petrology $\mathbf{2 7}$ $745-750$

Litvinovsky B A, Steele I M and Wickham S M 2000 Silicic magma formation in overthickened crust: Melting of charnockite and leucogranite at 15, 20 and $25 \mathrm{kbar}$; Journal of Petrology 41 717-737

Mahood G and Hildreth W 1983 Large partition coefficients for trace elements in high-silica rhyolites; Geochimica et Cosmochimica Acta $\mathbf{4 7}$ 11-30

McDonough W F and Sun S -s 1995 The composition of the Earth; Chemical Geology 120 223-253

Musselwhite D S, DePaolo D J and McCurry M 1989 The evolution of a silicic magma system: isotopic and chemical evidence from the Woods Mountains Volcanic Centre, eastern California; Contributions to Mineralogy and Petrology 101 19-29

Nash W P and Crecraft H R 1985 Partition coefficients for trace elements in silicic magmas; Geochim.et cosmochim Acta 49 2309-2322

Nash W P, Christiansen J N, Lee D-C and Halliday A N 1996 Temporal variation in ${ }^{143} \mathrm{Nd} /{ }^{144} \mathrm{Nd}$ and ${ }^{176} \mathrm{Hf} /{ }^{177} \mathrm{Hf}$ in silicic melts of Yellowstone; EOS Transcation, Amer. Geophys. Union $\mathbf{7 7} 823$

Nekvasil H 1992 Feldspar crystallization in felsic magmas: a review; Transaction Royal Society Edinburgh: Earth Sciences 83 399-407

Neogi S, Miura H and Hariya Y 1996 Geochemistry of Dongargarh volcanic rocks, Central India: Implications for the Precambrian mantle; Precambrian Research 76 77-91

Pankhurst R J and Rapela C R 1995 Production of Jurassic rhyolite by anatexis of the lower crust of Patagonia; Earth and Planetary Science Letters 134 23-36

Patiño Douce A E 1997 Generation of metaluminous A-type granites by low-pressure melting of calc-alkaline granitoids; Geology 25 743-746

Patiño Douce A E and Beard J 1995 Dehydration-melting of Biotite Gneiss and Quartz Amphibolite from 3 to $15 \mathrm{kbar}$; Journal of Petrology 36 707-738

Patiño Douce A E 1999 What do experiments tell us about the relative contributions of crust and mantle to the origin of granitic magmas? In: Fernández A A and Vigneresse J L (eds.) Understanding Granites: Integrating New and Classical Techniques; Geological Society of London Special Publication 168 55-75

Peccerillo A, Barberio M R, Yirgu G, Ayalew D, Barbieri M and Wu T W 2003 Relationships between Mafic and Peralkaline silicic mgmatism in continental Rift settings: a Petrological, Geochemical and isotopis study of the Gedemsa Volcano, Central Ethiopian Rift; Journal of Petrology 44 (11), 2003-2032

Philpotts A R 1990 Principles of Igneous and Metamorphic Petrology; Prentice-Hall of India Pvt. Ltd. $498 \mathrm{p}$

Rapp R P, Watson E B, 1986 Monazite solubility and distribution kinnetics: implications for the thorium and light rare earth chemistry of felsic magmas; Contributions to Mineralogy and Petrology 94 304-316

Rollinson H R 1993 Using Geochemical data: Evaluation, Presentation, Interpretation; Longman $352 \mathrm{p}$

Roy Abhinaba, Ramachandra H M, Bandyopadhyay B 2000 Supracrustal Belts and Their Significance in the Crustal Evolution of Central India; Geological Survey of India Special Publication 55 361-380

Rudnick R L and Presper T 1990 Geochemistry of intermediate/- to high pressure granulites. In: Granulites and Crustal Evolution. Vielzeuf D and Vidal Ph (eds.) Kluwer Acdemic Publishers, Netherlands

Rudnick R L, McLennan S M and Taylor S R 1985 Large ion lithophile elements in rocks from high-pressure granulite facies terrains; Geochimica et Cosmochimica Acta 49 1645-1655

Sarkar S N (1957-58) Stratigraphy and tectonics of the Dongargarh System, a new system in the Precambrians of Bhandara-Durg-Balaghat area, Bombay and Madhya Pradesh; Journal of Science and Engineering Research, I.I.T., Kharagpur, India 1 237-268, 2 145-160

Sarkar S N, Gopalan K and Trivedi J R 1981 New data on the geochronology of the Precambrians of BhandaraDurg, Central India. Indian Journal of Earth Sciences 8 131-151

Sarkar S N, Sarkar S S and Ray S L 1994 Geochemistry and genesis of the Dongargarh Supergroup Precambrian rocks in Bhandara-Durg Region, Central India. Indian Journal of Earth Sciences 21 117-126

Sensarma S 2001 Volcanic stratigraphy and petrology of the volcano-sedimentary sequence near Salekasa-Darekasa, Bhandara district, Maharashtra. Unpublished Ph. D. thesis, Jadavpur University, Calcutta

Sensarma S and Mukhopadhyay D 2003 New Insight on the stratigraphy and volcanic history of the Dongargarh Belt, Central India. Gond. Geol. Magz. Spl. Vol. 7 129-136 
Sensarma S, Palme H and Mukhopadhyay D 1999 Geochemical character of a SHMB-type magma from the early Proterozoic Dongargarh Supergroup, India. Beihefte zum European Journal of Mineralogy 11(1) 211

Sensarma S, Palme H and Mukhopadhyay D 2002 CrustMantle interaction in the Genesis of Siliceous High Magnesian Basalts (SHMB): Evidence from the Early Proterozoic Dongargarh Supergroup, India; Chemical Geology 187 21-37

Sensarma S, Hoernes S and Mukhopadhyay D 2004 Low $\mathrm{O}^{18}$ high-silica Rhyolite in the Palaeoproterozoic Dongargarh Group, Central India; 32nd International Geological Congress, Florence, Italy (published)

Shapiro L and Brannock W W 1962 Rapid analyses of silicate, carbonate and phosphate rocks; United States Geological Survey Bullettin 48 49-55

Shaw D M 1970 Trace element fractionation during anatexis; Geochimica et Cosmochimica Acta 34 237-242

Shivkumar K, Jain P K, Choudhary D K, Saxena V P 2003 Geochemistry of Supracrustals of Kotri-Dongargarh Supergroup; Gond. Geol. Magz. Spl. Vol. 7 217-239

Sinigoi S, Antonini P, Demarchi G, Longinellin A, Mazucchelli M, Negrini L and Rivalenti G 1991 Interactions of mantle and crustal magmas in the southern part of the Ivrea zone (Italy); Contributions to Mineralogy and Petrology 108 385-395

Spiegelman M and Kenyon P 1992 The requirements for chemical disequilibrium during magma migration; Earth and Planetary Science Letters 109 611-620

Taylor H P and Sheppard S M F 1986 Igneous rocks I: processes of Isotopic fractionation and isotope systematics. In: Stable isotopes in high temperature processes,
Valley J W, Taylor H P, O'Neil J R (eds): Reviews in Mineralogy 16, Mineralogical Society of America

Taylor H P 1980 The effects of assimilation of country rocks by magmas on ${ }^{18} \mathrm{O} /{ }^{16} \mathrm{O}$ and ${ }^{87} \mathrm{Sr} /{ }^{86} \mathrm{Sr}$ systematics in igneous rocks; Earth and Planetary Science Letters $\mathbf{4 7}$ $243-254$

Taylor S R and McLennan S M 1985 The continental crust: its composition and evolution; Blackwell Scientific Publications

Thompson A B 1999 Some time-space relationship for crustal melting and granitic intrusion at various depths. In: Understanding Granites: Integrating New and Classical Techniques. Fernández A A and Vigneresse J L (eds) Geological Society of London Special Publication 1687 25

Watson E B 1988 The role of accessory minerals in granitoid geochemistry. In: First Hutton Meeting on the origin of Granite and Related Rocks, Vol. 1. Edinburgh: Royal Society of Edinburgh, pp. 19-20

Watson E B and Harrison T M 1983 Zircon saturation revisited: temperature and compositional effects in a variety of crustal magma types; Earth and Planetary Science Letters 64 295-304

Weaver G L 1980 Rare-earth geochemistry of Madras granulites. Contributions to Mineralogy and Petrology $\mathbf{7 1}$ 271-279

Whalen J B, Currie K L and Chappell B W 1987 A-type granites: geochemical characteristics, discrimination and petrogenesis; Contributions to Minearalogy and Petrology 95 407-419

Yoder H S 1973 Contemporaneous basaltic and rhyolitic magmas; American Mineralogist 58 153-171 